\title{
Dynamical-Statistical Hybrid Seasonal Prediction of Tropical Cyclone Track Density Over Western North Pacific
}

\section{Daquan Zhang}

Beijing Climate Center https://orcid.org/0000-0001-5867-9069

Lijuan Chen ( $\nabla$ chenlj@cma.gov.cn )

Beijing Climate Center

\section{Research Article}

Keywords: Tropical cyclone, Track density, ENSO, Seasonal prediction

Posted Date: September 8th, 2021

DOl: https://doi.org/10.21203/rs.3.rs-875331/v1

License: (c) (1) This work is licensed under a Creative Commons Attribution 4.0 International License.

Read Full License 


\section{Abstract}

Compared with total account of basin-wide tropical cyclones (TC) genesis, the prevailing tracks of TC activity and its potential of landfalling is more important for disaster prevention. Despite its relatively lower predictability, a statistical-dynamical hybrid prediction model was developed based on the knowledge of the physical mechanism between western North Pacific (WNP) TC activity and related large-scale environmental fields from July to September. The leading modes of spatial-temporal variation of WNP TC tracks density its climatological peak season (July to September) was extracted using empirical orthogonal function (EOF) decomposition. The interannual variation of leading EOF modes of WNP TC track density was predicted using multiple linear regressions (MLR) method based on predictors selected by correlation analysis of both observational and Beijing Climate Center climate system model version 1.1 (BCC_CSM1.1) hindcast data. The predicted spatial distribution of WNP TC tracks density was obtained through weighted composite of forecasting EOF modes according to its variance explained respectively. Results of one-year-out cross validation indicates that forecast model well captures the interannual variation of WNP TC prevailing moving tracks, especially in South China Sea (SCS) and southeastern quadrant of WNP. The prediction skill enhanced with decreased forecast lead time, with anomaly correlation coefficient (ACC) of northern SCS and southeast quadrant of WNP reaches 0.6 for the period 1991-2020 with one month forecast lead time. Forecast assessment based on different ENSO phases indicate that source of predictability of WNP TC tracks was mainly originate from ENSO events, especially strong El Niño events.

\section{Introduction}

Tropical cyclones (TC) often bring torrential rainfall, strong wind gusts and storm surges to the coastal regions, causing enormous social-economic losses (Zhang et al. 2009; Li et al. 2017; Ye et al. 2019). The western North Pacific (WNP) is one of the most active basin of TC activity, features more than one-third of global TC on average (Mei et al. 2015). Under the background of global warming, the intensity and destructive power of TC over WNP has been increased significantly (Park et al. 2014; Liu et al. 2020). Therefore, skillful seasonal prediction of TC activity over WNP, especially landfalling TC is crucial to disaster prevention and mitigation.

Operational seasonal TC forecasts for WNP basin has been issued since 1990s (Klotzbach et al. 2019). The products of TC seasonal forecast focus on the statistics of TC activity, such as frequency of TC genesis and landfall, accumulated cyclone energy (ACE), mean genesis location, track density, etc. TC track density integrates information of the moving path, number and location of TC genesis and became a widely used metrics of forecast (Mei et al. 2015). The tools and methodologies utilized in seasonal TC forecasts can be divided into three categories: statistical approaches, dynamical models and so-called hybrid statistical-dynamical models (Zhan et al. 2012; Kim et al. 2017). In statistical models, empirical relationship between predictor and predictand based on lagged correlations from previous seasons was utilized for TC prediction (Kim et al. 2010; Goh and Chan 2012; Liu and Chan 2012). While in dynamical $y$ based on the model output according to predefined criteria 
(Vitart et al. 1997; Camargo and Zebiak 2002; Alessandri et al. 2011). The source of TC predictability on seasonal time scale originates from the slow evolving large scale atmospheric circulation background and oceanic thermodynamics conditions (Zhan et al. 2012). Compared with extreme weather and climate events, the global coupled model (GCM) indicates relatively higher skill in simulating and prediction of large scale atmospheric and oceanic variables, such as geopotential height and sea surface temperature (SST) (Kang et al. 2009). In hybrid statistical-dynamical models, both the statistical relationship between climatic factors and with physical background and useful information of model output was utilized, and serves as a promising way to produce skillful seasonal TC prediction.

As the strongest signal in tropical air-sea system on inter-annual timescale, the relationship between ENSO and WNP TC activity has been widely discussed (Camargo et al. 2007; Zhao et al. 2010; Li and Zhou. 2012; Yonekura and Hall 2014; Patricola et al. 2018; Wu et al. 2018; Choi et al. 2019). While the correlation between inter-annual variability of TC frequency over WNP and ENSO is not significant (Camargo and Sobel 2005), the location of TC genesis was strongly modulated by ENSO (Wang and Chan 2002). In El Nino years, there is usually a southeastward displacement of the mean TC genesis location. For most of strong El Niño decaying years, the TC formation over WNP was suppressed before its peak season, but turns to be active in late summer and fall (Wang et al. 2019), resulting in little variation of annual TCs account. The modulating effect of ENSO on TC activity shows a high degree of seasonality (Mei et al. 2015). The relationship between ENSO and WNP TC activity is different for early (April to June, AMJ), peak (July to September, JAS) and late (October to December, OND) season (Wang et al. 2013a). Moreover, as a typical monsoon region, the climatological background atmospheric circulation of WNP changed significantly from summer to autumn (Ko and Liu 2019). Taken TC activity of whole typhoon season as the forecasting object might obscures a lot of predictive information. On the other hand, during the peak season of WNP TC activity, the mean atmospheric circulation provides more representative features of steering flow of TC's prevailing moving tracks. In this study, TC track density of peak season of WNP TC activity was selected as the object of forecast.

While TC track density over WNP was strongly influenced by ocean external forcing, it also shows certain randomness owing to the chaotic nature internal dynamic process of atmosphere. Compared with basin wide integrated measures, such as total account of TC numbers, the TC track patterns are more complex and less predictable (Mei et al. 2015; Sun et al. 2020). The representative WNP TC tracks can be classified into several clusters using different methods, and each cluster exhibits distinctive characteristics of its intensity, life span, seasonality, landfall region and induced rainfall (Kim et al. 2011; Kim and Seo 2016). Skillful prediction of all details of TC tracks and landfall, especially on the seasonal timescale is rather challenging. In this work we only focus on the large scale patterns of TC activity interannual variability. Moreover, the underlying mechanisms of leading mode of TC activity over WNP has been extensively discussed in previous studies (Liu and Chan 2008) the research findings also serve as support of impact factor selection in the forecast model construction.

The result of this paper is organized as follows. Section 2 describes datasets of both observational and Loading [MathJax]/jax/output/CommonHTML/jax.js zed. Section 3 presents the climate factors and its possible 
underlying mechanisms in regulating WNP TC activities. The assessment of predictive skill of forecast model constructed was described in Sect. 4. The main conclusions and a brief discussion are given in Sect. 5.

\section{Data And Methods 2.1 TC track data}

The observational TC track data used was extracted from the TC-best track dataset (1949-present) created by Shanghai Typhoon Institute of China Meteorological Administration (Ying et al. 2014), which is available at http://tcdata.typhoon.org.cn/zjljsjj_zlhq.html. The dataset documents TCs' location, intensity, moving path, as well as its landfall at a 6-hour interval. Only TC with maximum 10-m wind speed exceeds $17.2 \mathrm{~m} \mathrm{~s}^{-1}$ was considered. It should be noted that the temporal resolution of track data has been increased to 3 hours with respect to all landfalling TC hit China since 2017.

The TC track density is calculated on $1^{\circ} \times 1^{\circ}$ grid basis. For each grid within WNP and South China Sea (SCS), TC track density is defined as TC days within $8^{\circ} \times 8^{\circ}$ grid centered at this grid point. The large grid is utilized to reduce the noise, which is less predictable. Smaller grid produces similar results in extracting the large scale spatial patterns of TC track density. Instead of the frequently used extended boreal summer, TC track density of July, August and September was chosen as our study objects. The main reasons are twofold. First, late summer and early autumn are the most active season of WNP TC activity, with July, August and September ranks as the top 3 month of both number of WNP TC genesis and landfalling TC. TC activity is so frequent that the prevailing steering flow can be well represented by large scale wind fields. Second, due to the seasonal variation of climatological background from early summer to late autumn, the large scale environmental field, steering flow and it relationship with the WNP TC activity changed throughout the extended boreal summer, typically from May to October (Zhao et al. 2020; Zhao et al. 2021). Longer duration of research objects might also obscure its correlation with environmental field, given individual TC as typical event of synoptic scale. For example, while ENSO strongly modulates WNP TC activity on seasonal time scale (Wang et al. 2002), the annual total numbers of WNP TC are virtually uncorrelated with ENSO indices (Lander 1994).

Furthermore, EOF analysis is employed to extract the leading modes of the variability in TC track density, and linear correlation and regression analyses are utilized to detect the signal in SSTs and atmospheric conditions associated with each identified mode. Two-tailed Student's $s$ test was performed to test the statistical significant of correlation analysis.

\subsection{Observational and Model hindcast data}

Seasonal reforecasts from Beijing Climate Center Climate System Model version 1.1 (BCC_CSM1.1) has been used as predictor field (Wu et al. 2013). BCC_CSM1.1 became operational since December of 2014, and exhibits higher predictive skill compared with BCC_CM1.0 in both large scale atmospheric circulation 
Atmospheric General Circulation Model (BCC_AGCM2.2), with T106 horizontal resolution and 26 vertical layers (Collins et al. 2006; Wu et al. 2014). The land surface component BCC_AVIM1.0 was developed based on National Center of Atmospheric Research-Community Land Model version 3 (NCAR-CLM3) and Atmospheric Vegetation Interaction Model version 2 (AVIM2) (Ji et al. 2008). The ocean model (MOM_L40) was modified from the Modular Ocean Model (MOM4) which was developed by Geophysical Fluid Dynamics Laboratory (GFDL) (Griffies et al. 2005). The sea ice component was the Sea Ice Simulator (SIS) (Winton, 2000). All components are fully coupled using CPL5. BCC_CSM1.1 hindcast dataset was composed of 13 month reforecasts initiated monthly with 24 ensemble members for the period from 1991 to 2020.

The observational SST and atmospheric circulation data are from the National Oceanic and Atmospheric Administration (NOAA) Extended Reconstructed SST version 5 (ERSSTv5) (Huang et al. 2017) and the National Centers for Environmental Prediction and National Center for Atmospheric Research Reanalysis 1 (NCEP/NCAR-R1) (Kalnay et al. 1996) with horizontal resolution of $1^{\circ} \times 1^{\circ}$ and $2.5^{\circ} \times 2.5^{\circ}$, respectively. Geopotential height (GPH), mean sea level pressure (SLP), zonal wind and outgoing longwave radiation (OLR) of different vertical layers were utilized. The vertical wind shear (VWS) was defined as the difference between zonal wind at 200 and $850 \mathrm{hPa}$. Anomalies were obtained based on climatological mean of 30 years (1991-2020).

\section{Spatial-temporal Characteristics Of Wnp Tc Track Density Distribution}

EOF analysis of the TC track density indicates that TC activity over WNP can be represented by three distinct spatial patterns. The leading EOF (hereafter EOF1) mode explains $\sim 20.2 \%$ of the total variance exhibits a basin wide mode, i.e. consistent increased or decreased TC activity over the whole WNP (Fig. 1a,b), which is in accordance with results for extended boreal summer of previous studies (Mei et al. 2015; Zhao et al. 2020). The 2nd EOF (hereafter EOF2) explains 14.3\% of the total variance, with opposite anomalies in northern SCS and east of the Philippines, separated by $130^{\circ} \mathrm{E}$. The spatial pattern of EOF2 (Fig. 1c,d) is consistent with the southeastward (northwestward) shift of TC genesis over WNP due to large scale environmental field anomalies associated with ENSO (Wang and Chan, 2002). The 3rd EOF (hereafter EOF3) explains 8.7\% of the total variance (Fig. 1e, f), it main features north-south difference in East China Sea and east of the Philippines. Both PC1 and PC2 shows significant interannual variability, while PC3 illustrates lower frequency variations compared with PC1 and PC2, with dominant negative values in mid 1990s and 2005 to 2015, positive values from the end of last century to the beginning of this century. The spatial pattern associated with PC3 also concurrent with a poleward migration of tropical cyclones toward East Asia coast, which might be connected with the PDO phase change and Hadley circulation expansion (Wang and Toumi 2021). Note that the combination of three leading EOF mode listed above captures overall spatial patterns of TC activity over WNP. Considering the representativeness of each EOF mode and its predictability, we only focus on the primary TC track density patterns and extracted useful predictive information from both observational and model output.

Loading [MathJax]/jax/output/CommonHTML/jax.js

Page 5/24 


\section{Dynamical-statistical Prediction Of Tc Track Density 4.1 Physical basis of predictor selection for each EOF mode}

Figure 2 shows distribution of the correlation coefficient between the PC1 and SST anomalies, geopotential height at $850 \mathrm{hPa}$ (hereafter $\mathrm{H} 850$ ) and VWS from both observational dataset and model hindcast during 1991-2020. There are significant negative correlations between PC1 and equatorial central Pacific (Fig. 2a, b). This relationship has been well documented in previous studies. The anomalous convection associated with central Pacific warming would produce a poleward extension of anomalous westerlies over WNP, leading to a strengthened and eastward displacement of monsoon trough (MT), which is in favor of TC genesis over WNP (Wang and Chan. 2002; Patricola et al. 2018; Wu et al. 2018; Zhang et al. 2020). The prevailing tracks of WNP TC also strongly modulated by the western Pacific subtropical high (WPSH) (Wang et al. 2013b; Camp et al. 2020) (Fig. 2c, d). The numbers of landfalling TCs would be reduced (enhanced) by intensified (weakend) WPSH. The prevailing TC tracks would be westward while WPSH is strong. When WPSH is weakened and shifted eastward, TC tracks can recurve northwards and affect East China, Korea and Japan. Moreover, positive VWS anomalies and over subtropical WNP while negative in mid-latitude is in favor of more TC activities (Fig. 2e, f). Negative VWS anomalies over WNP can be favorable atmospheric conditions for TC formation since more instabilities could be frequently developed in an organized convection system (Gray 1998).

To ensure the stability and robustness of the predictors, only predictors well above the $90 \%$ confidence level in both observational and model hindcast result was retained. For example, the SST of western Pacific warm pool were not selected because of the model's poor ability in representing this relationship, although warm SST was in favor of TC genesis and intensification. The correlation between model hindcast and PC1 was comparatively weak on the whole. However, the spatial distribution of anomaly correlation coefficient (ACC) between PC1 and environmental fields are well captured by BCC_CSM1.1, despite discrepancies still exists, such as H850 in the SCS and East of Philippines (Fig. 2b). This discrepancy might be associated with weaken and northward shifted WPSH in model simulation, which is a common bias in CMIP5 models (He et al. 2014; Zhang et al. 2020). Three predictors were selected: SST anomalies in the central Pacific $\left(10^{\circ} \mathrm{S}-10^{\circ} \mathrm{N}, 170^{\circ} \mathrm{E}-130^{\circ} \mathrm{W}\right), \mathrm{H} 850$ over western and central north Pacific $\left(10^{\circ} \mathrm{N}-30^{\circ} \mathrm{N}, 120^{\circ} \mathrm{E}-160^{\circ} \mathrm{W}\right)$, VWS over tropical WNP $\left(0-15^{\circ} \mathrm{N}, 120^{\circ} \mathrm{E}-170^{\circ} \mathrm{W}\right)$.

The interannual variation of PC2 was connected to the canonical eastern Pacific ENSO (Fig. 2a) (Mei et al. 2015). The inverse variation of TC track density between SCS and WNP was associated with the eastward or westward shift of TC genesis location. Suppressed TC formation over northwest quadrant while enhanced TC generation over southeastern quadrant of WNP was associated both oceanic and atmospheric responses of El Nino forcing (Wang and Chan. 2002). Previous studies indicate that compared with Nino-3.4 indices, mega-ENSO index (Wang et al. 2013c) (Fig. 3a, b) exhibits higher predictive skill in seasonal forecasting of WNP TC activity (Zhan et al. 2017; Sun et al. 2020). Besides SST anomalies, the OLR of equatorial eastern Pacific $\left(15^{\circ} \mathrm{S}-15^{\circ} \mathrm{N}, 140^{\circ} \mathrm{W}-90^{\circ} \mathrm{W}\right)$ associated with Walker ors. 
The WNP tracks also exhibits significant inter-decadal variations with decreased westward and northeastward TC recurving tracks since early 2000s (Fig. 1c, 1d). Studies shows the modulation effect of Pacific decadal variability on both WNP TC genesis and prevailing tracks (Liu and Chan 2008; Zhao and Wu 2014; He et al. 2015; Liu et al. 2019). According to existed research and correlation analysis (Fig. 3a, 3b), Pacific decadal oscillation (PDO) index was taken into account to represent the influence of Pacific decadal variability on WNP TC activity, which was defined as the leading principal component of North Pacific (poleward of $20^{\circ} \mathrm{N}$ ) monthly SST variability (Mantua et al. 1997).

The EOF3 of TC track density was associated with a north-south seesaw spatial pattern (Fig. 1e, f). Northward migration of mean latitudinal location of WNP TC genesis and tracks was revealed in recent studies (He et al. 2015; Wang and Toumi 2021). The ACC of eastern tropical Indian Ocean $\left(20^{\circ} \mathrm{S}-10^{\circ} \mathrm{N}\right.$, $80^{\circ} \mathrm{E}-120^{\circ} \mathrm{E}$ ) pass significant test at $90 \%$ confidence level and selected as predictor of PC3. Previous studies reveal that eastern Indian Ocean SST anomalies significantly affect both summer monsoon and equatorial Kelvin wave activity over western Pacific and modulate TC activity (Zhan et al. 2011; Ha et al. 2015). Besides, the correlation between SST anomalies of Kuroshio and its extension (K-KE) area $\left(25^{\circ} S-\right.$ $45^{\circ} \mathrm{N}, 140^{\circ} \mathrm{E}-150^{\circ} \mathrm{W}$ ) was significant and thus selected as predictors(Fig. $4 \mathrm{a}, 4 \mathrm{~b}$ ). The positive SST anomaly in K-KE was favorable for the warm high over Northeast Asia and Japan, leading to the northward displacement of WPSH (Ding et al. 2019), give rise to more northward TC over WNP (Camp et al. 2019, 2020).

\subsection{Predictive skill of BCC_CSM1.1 for selected background environmental fields}

The predictive skill of BCC_CSM1.1 for large scale environmental fields associated with WNP TC was evaluated, including SST, H850, VWS and OLR (Fig. 5). The distribution of anomaly correlations between the observed and model hindcasts for JAS over 1991-2020 initated in June (1-month lead) was given. The prediction skill of interannual variation of SST in JAS is the highest, with ACC exceeds 0.8 in equatorial Pacific (Fig. 5a). BCC_CSM1.1 also well captures the interannual variability of H850, with ACC for most regions between $30^{\circ} \mathrm{N}$ and $30^{\circ} \mathrm{S}$ passed significant test at $95 \%$ confidence level. For eastern Indian Ocean, southern warm pool and parts of east equatorial Pacific, the ACC reaches 0.8 (Fig. 5b). Significant skill for VWS is shown over the warm pool and central equatorial Pacific, where the VWS is an important factor for WNP TC activity. Reduced VWS and eastward extension of monsoon trough provides a favorable condition for TC genesis (Fig. 5c) (Wu et al. 2012; Cao et al. 2016). Significant skill for OLR can be found over equatorial central and eastern Pacific, subtropical northeastern Pacific and parts of western Pacific warm pool, with ACC reaching 0.8 in equatorial eastern Pacific (Fig. 5d).

\subsection{Validation for WNP TC track density prediction}

The procedure of forecast model construction can be divided into three steps. The first step is multi-linear regression between time series of PCs and selected predictors for each leading mode of EOF analysis.

Loading [MathJax]/jax/output/CommonHTML/jax.js eriod was applied to the forecast of target year to obtain 
forecast PCs. Finally, the spatial distribution of track density was reconstructed by composite of leading EOF modes forecasted multiplied by variance explained.

Skillful forecast of PCs is vital for the overall performance of TC track density prediction. The regression analysis is first applied to the whole hindcast period to check the ability of selected predictors to reconstruct leading PCs. Figure 6 shows the regressed time series of PCs based on selected predictors of both observational and model hindcast results. The interannual variation of three leading PC are well captured by regressed models. ACC between observational and regressed PCs passed significant test at 99\% confidence level, with PC1 based on observational predictors ranks the highest.

On the other hand, to test the prediction skill of forecast model in real time forecast, one-year-out cross validation was utilized (Fig. 7). For random chosen target year of prediction among 1991-2020, the other 29 years was utilized as training set for both observational and model hindcast. Regression analysis and forecast model construction based on training set was repeated for 30 times until all years have been chosen as target years of prediction. As shown in Fig. 7, the interannual variation of reforecast PCs is in good agreement with observations. The ACC between observational and reforecast based BCC_CSM1.1 for three PCs are $0.52,0.54$ and 0.62 , all passed significant test at $99 \%$ confidence level.

TC activity over WNP and SCS is regional dependent. To examine the spatial distribution of prediction skill of TC track density, WNP $\left(0-45^{\circ} \mathrm{N}, 120^{\circ} \mathrm{E}-180\right)$ is partitioned into 4 sub-regions with $20^{\circ} \mathrm{N}$ and $140^{\circ} \mathrm{E}$ serve as the dividing line between the south and north and between the east and west following other studies (Wang and Chan 2002; Wang et al. 2013a) but with slight modification (Fig. 8). Figure 9 shows that forecast for SCS and southeast quadrant of WNP exhibits higher skill, with ACC of forecast initiated in June exceeds 0.6.

The relationship between prediction skill and initial date of hybrid model was evaluated. The prediction skill shows an overall increasing trend with decreased forecast lead time, indicates the source of predictability of TC tracks originates not only external forcing, but also initial state of atmospheric-ocean coupled system. The spatial distribution of ACC for different initial date was given (Fig. 10). The interannual variation TC activity in southeast quadrant of WNP was captured well. It is also noted that in the forecast initiated in April and May, TC tracks passing East China Sea and SCS are in good agreement with those from observations.

As the strongest signal in air-sea system, ENSO is an important source of predictability in seasonal to inter-annual timescale (Wang et al 2013a, b). Wang and Chan (2002) noted that WNP TC activities in July-December are noticeably predictable under the background of strong ENSO events in preceding winter and spring. The relationship between predictive skill of WNP TC track density and different phases of ENSO was investigated. First, all El Niño and La Niña events from 1991 and 2020 was determined based on Niño 3.4 index (Ren et al. 2018). El Niño years are 1991/92, 1994/95, 1997/98, 2002/03, 2004/05, 2006/07, 2009/10, 2014/15, 2015/16, 2018/19. La Niña years are 1995/96, 1998/99, 1999/00, 2000/01, 2005/06, 2007/08, 2008/09, 2010/11, 2011/12, 2016/17, 2017/18, 2020/2021. Due to the Loading [MathJax]/jax/output/CommonHTML/jax.js . most El Niño (La Niña) events peak in boreal winter, all 
years was classified into El Niño (La Niña) developing, decaying or neutral phases. In order to ensure the reliability of the assessment, all 24 ensemble members of model hindcasts were utilized. The averaged ACC of all forecast members was used to represent the prediction skill of hybrid model.

The prediction skill of hybrid model was investigated according to different ENSO phases. Forecast skills for the El Niño decaying years is higher than those for both neutral and La Niña decaying years, especially in southeast quadrant of WNP (Fig. 11). The southwest quadrant of WNP shows higher skill in neutral years, while the southeast quadrant is the highest in La Niña decaying years. The forecast of TC track density in ENSO developing years is generally less skillful compared with decaying years (Fig. 12). Relative to El Niño, the La Niña developing years show a slightly higher skill. This might be associated with the fact that most La Niña developed in El Niño years. Meanwhile, the regions with ACC passing significant test was mainly located in SCS. Since the relationship between ENSO and WNP TC activity depends on the intensity of ENSO events, only strong El Niño (La Niña) events have significant influence on WNP TCs (Wang and Chan 2002). The intensity of ENSO events shows a remarkable positive asymmetry between its two phases, i.e. the strongest El Niño is stronger than the strongest La Niña (An and Jin 2004; Liang et al. 2017). This disparity in prediction skill indicates the source of predictability of WNP TC tracks might be originate from ENSO events, especially strong El Niño events.

\section{Conclusions And Discussion}

A statistical-dynamical hybrid forecast model was developed based on the physical mechanism between WNP TC activity and large scale ocean-atmosphere variability during boreal summer. TC activity from July to September was selected as forecast target partly since during its peak season the seasonal mean atmospheric circulation can well represent the steering flow of TCs, partly because seasonality of ENSO's influence reported in previous studies (Wang et al. 2013a; Choi et al. 2019). One-year-out cross validation shows that hybrid model well captures the spatial distribution of WNP TC track density, and the performance enhanced with decrease forecast lead time. SCS and southeastern quadrant of WNP features higher prediction skill, with ACC of forecast initiate in June reaches 0.6 , passing significant test at $99 \%$ confidence level, indicates its potential of application in seasonal forecast of WNP TC activity. Further assessment of prediction skill based on different ENSO phases indicate that source of predictability of WNP TC tracks might be originate from ENSO events, especially strong El Niño events.

Is should be noted that relationship between PC2, PC3 and large scale environmental fields is comparatively lower than PC1, while the EOF1 represents an overall more or less TC activity over WNP and SCS. The variation PC2 and PC3 was associated with ENSO and decadal variability of North PacifiC SST anomaly, suggesting the importance of taken predictors of decadal timescale into account, which is also consistent with previous studies of WNP TC tracks (Camargo et al. 2007; Zhao et al. 2014; Zhao et al. 2018). Despite its ability of represent the relationship between WNP TC activity and environmental fields, systematic bias still exists, especially in the western Pacific warm pool. The numerical model's capability in simulate the ocean atmosphere circulation and its relationship with WNP TC is vital for 
In this study, we have demonstrated the skillful seasonal prediction of prevailing WNP TC tracks. Both atmospheric and oceanic factors from seasonal to decadal time scale were considered. Additional forecast skill may arise from ensemble forecast of multiple numerical models to eliminate systematic bias in simulation and prediction, regression methods which taken nonstationarity of relationship between predictors and predictand into account, since the relationship between WNP TC activity and atmospheric and oceanic fields might be modulated by decadal factors (Koltzbach 2011). Nevertheless, the statistical-dynamical hybrid prediction model developed can be applied in operation and provide useful information for TC associated disaster mitigation and prevention.

\section{Declarations}

\section{Acknowledgements}

This research was jointly supported by the National Key Research and Development Project of China (2017YFC1502303), the National Key Research and Development Program on Monitoring, Early Warning and Prevention of Major Natural Disaster (2018YFC1506000), the State Key Program of the National Natural Science of China (41730964), and the National Natural Science Foundation of China (41975091, 41975076 and 41605078).

\section{References}

1. Alessandri A, Borrelli A, Gualdi S, Scoccimarro E, Masina S (2011) Tropical cyclone count forecasting using a dynamical seasonal prediction system: Sensitivity to improved ocean initialization. J Clim 24: 2963-2982. https://doi.org/10.1175/2010JCLI3585.1

2. An S-I, Jin F-F (2004) Nonlinearity and Asymmetry of ENSO. J Clim 17: 2399-2412. https://doi.org/10.1175/1520-0442(2004)017<2399:NAAOE>2.0.C0;2

3. Camargo S, Robertson A, Gaffney S, Smyth P, Ghil M (2007) Cluster analysis of typhoon tracks. Part II: Large-scale circulation and ENSO. J Clim 20: 3654-3676. https://doi.org/10.1175/JCLI4203.1

4. Camargo S, Robertson J, Gaffney S, Smyth P, Ghil M (2007) Cluster analysis of typhoon tracks: Part 刃: Large-Scale circulation and ENSO. J Clim 20: 3654-3676. https://doi.org/10.1175/JCLI4203.1

5. Camargo S, Sobel A (2005) Western North Pacific tropical cyclone intensity and ENSO. J Clim 18: 2996-2006. https://doi.org/10.1175/JCLI3457.1

6. Camargo S, Zebiak S (2002) Improving the detection and tracking of tropical storms in atmospheric general circulation models. Weather Forecast 17: 1152-1162. https://doi.org/10.1175/15200434(2002)0172.0.C0;2

7. Camp J, Bett P, Golding N, Hewitt C, Mitchell T, Scaife A (2020) Verification of the 2019 GloSea5 Seasonal Tropical Cyclone Landfall Forecast for East China. J Meteor Res 34: 917-925. https://doi.org/10.1007/s13351-020-0043-5 
8. Camp J, Roberts M, Comer R, Wu P, MacLachlan C, Bett P, Golding N, Toumi R, Chan JCL (2019) The western Pacific subtropical high and tropical cyclone landfall: Seasonal forecasts using the Met Office GloSea5 system. Quart J R Meteor Soc 145: 105-116. https://doi.org/10.1002/qj.3407

9. Cao X, Chen G, Li T, Ren F (2016) Simulations of tropical cyclogenesis associated with different monsoon trough patterns over the western North Pacific. Meteor Atmos Phys 128: 491-511. https://doi.org/10.1007/s00703-015-0428-7

10. Choi Y, Ha K-J, Jin F-F (2019) Seasonality and El Niño diversity in the relationship between ENSO and western North Pacific tropic cyclone activity. J Clim 32: 8021-8045. https://doi.org/10.1175/JCLI-D18-0736.1

11. Collins W, Rasch P, Boville B, Hack J, McCaa J, Williamson D, Briegleb B, Bitz C, Lin S-J (2006) The formulation and atmospheric simulation of the Community Atmosphere Model version 3 (CAM3). J Clim 19: 2144-2161. https://doi.org/10.1175/JCLI3760.1

12. Ding T, Yuan Y, Zhang J, Gao H (2019) 2018: The Hottest Summer in China and Possible Causes. J Meteor Res 33: 577-592. https://doi.org/10.1007/s13351-019-8178-y

13. Goh AZ, Chan JCL (2012) Variations and prediction of annual number of tropical cyclone affecting Korea and Japan. Int J Climatol 32: 178-189. https://doi.org/10.1002/joc.2258

14. Gray W M (1998) The formation of tropical cyclones. Meteor Atmos Phys 67: 37-69. https://doi.org/10.1007/BF01277501

15. Griffies S, Gnanadesika A, Dixon K, Dunne J, Gerdes R, Harrison M, Rosati A, Russell J, Samuels B, Spelman M, Winton M, Zhang R (2005) Formulation of an ocean model for global climate simulations. Ocean Science 1: 45-79. https://doi.org/10.5194/osd-2-165-2005

16. Ha Y, Zhong Z, Yang X, Sun Y (2015) Contribution of East Indian Ocean SSTA to western North Pacific tropical cyclone activity under El Niño/La Niña conditions. Int J Climatol 35: 506-519. https://doi.org/10.1002/joc.3997

17. He C, Zhou T (2014) The two interannual variability modes of the western North Pacific subtropical high simulated by 28 CMIP5-AMIP models. Clim Dyn 43: 2455-2469.

https://doi.org/10.1007/s00382-014-2068-x

18. He H, Yang J, Gong D, Mao R, Wang Y, Gao M (2015) Decadal changes in tropical cyclone activity over the western North Pacific in the late 1990s. Clim Dyn 45: 3317-3329. https://doi.org/10.1007/s00382-015-2541-1

19. Huang B, Thorne P, Banzon V, Boyer T, Chepurin G, Lawrimore J, Menne M, Smith T, Vose R, Zhang HM (2017) Extended Reconstructed Sea Surface Temperature, Version 5 (ERSSTv5): Upgrades, Validations, and Intercomparisons. J Clim 30: 8175-8205. https://doi.org/10.1175/JCLI-D-16-0836.1

20. Ji J, Huang M, Li K (2008) Prediction of carbon exchanging between China terrestrial ecosystem and atmospheric in 21st century. Sci China Earth Sci 51: 885-898. https://doi.org/10.1007/s11430-0080039-y

21. Kalnay E, Kanamitsu M, Kistler R, Collins W, Deaven D, Gandin L, Iredell M, Saha S, White G, Woollen Loading [MathJax]/jax/output/CommonHTML/jax.js Ts W, Janowiak J, Mo K, Ropelewski C, Wang J, Leetmaa A, 
Reynolds R, Jenne R, Joseph D (1996) The NCEP/NCAR 40-Year Reanalysis Project. Bull Amer Meteor Soc 77: 437-472. https://doi.org/10.1175/1520-0477(1996)077<0437:TNYRP>2.0.C0;2

22. Kang H, Park C-K, Hameed S, Ashok K (2009) Statistical downscaling of precipitation in Korea using multimodel output variables as predictors. Mon Wea Rev 137: 1928-1939. https://doi.org/10.1175/2008MWR2706.1

23. Kim H, Ho C, Chu P, Kim J (2010) Seasonal prediction of summertime tropical cyclone activity over the East China Sea using the least absolute deviation regression and the Poisson regression. Int $\mathrm{J}$ Climatol 30: 210-219. https://doi.org/10.1002/joc.1878

24. Kim H-K, Seo K-H (2016) Cluster analysis of tropical cyclone tracks over the western North Pacific using self-organizing map. J Clim 29: 3731-3751. https://doi.org/10.1175/JCLI-D-15-0380.1

25. Kim H-S, Kim J-H, Ho C-H, Chu P-S (2011) Pattern classification of typhoon tracks using the fuzzy Cmeans clustering method. J Clim 24: 488-508. https://doi.org/10.1175/2010JCLI3751.1

26. Kim O, Kim H, Lee M, Min Y (2017) Dynamical-statistical seasonal prediction for western North Pacific typhoons based on APCC multi-models. Clim Dyn 48: 71-88. https://doi.org/10.1007/s00382016-3063-1

27. Klotzbach P (2011) El Niño-Southern Oscillation's impact on Atlantic basin hurricanes and U.S. landfalls. J Clim 24: 1252-1263. https://doi.org/10.1175/2010JCLI3799.1

28. Klotzbach P, Blake E, Camp J, Caron L, Chan JCL, Kang N, Kuleshov Y, Lee S, Murakami H, Saunders M, Takaya Y, Vitart F, Zhan R (2019) Seasonal tropical cyclone forecasting. Trop Cyc Res Rev 8: 134149. https://doi.org/10.1016/j.tcrr.2019.10.003

29. Ko KC, Liu JH (2019) Impact of interannually varying background circulation on summertime wave pattern and tropical cyclone tracks in the western North Pacific. Clim Dyn 53: 2249-2263. https://doi.org/10.1007/s00382-019-04823-z

30. Lander MA (1994) An exploratory analysis of the relationship between tropical storm formation in the western North Pacific and ENSO. Month Wea Rev 122: 636-651. https://doi.org/10.1175/15200493(1994)122<0636:AEAOTR>2.0.C0;2

31. Liang J, Yang X, Sun D (2017) Factors Determining the Asymmetry of ENSO. J Clim 30: 6097-6106. https://doi.org/10.1175/JCLI-D-16-0923.1

32. Li R, Zhou W (2012) Changes in western North Pacific tropical cyclones associated with the El NiñoSouthern Oscillation cycle. J Clim 25: 5864-5878. https://doi.org/10.1175/JCLI-D-11-00430.1

33. Li R, Zhou W, Shun C, Lee T (2017) Changes in destructiveness of landfalling tropical cyclones over China in recent decades. J Clim 30: 3367-3379. https://doi.org/10.1175/JCLI-D-16-0258.1

34. Liu C, Zhang W, Geng X, Stuecker M, Jin F-F (2019) Modulation of tropical cyclones in the southeastern part of western North Pacific by tropical Pacific decadal variability. Clim Dyn 53: 44754488. https://doi.org/10.1007/s00382-019-04799-w

35. Liu K, Chan JCL (2012) Interannual variation of Southern Hemisphere tropical cyclone activity and seasonal forecast of tropical cyclone number in the Australian region. Int J Climatol 32: 190-202. 
36. Liu KS, Chan JCL (2008) Interdecadal variability of western North Pacific tropical cyclone tracks. J Clim 21: 4464-4476. https://doi.org/10.1175/2008JCLI2207.1

37. Liu L, Wang Y, Zhan R, Xu J, Duan Y (2020) Increasing destructive potential of landfalling tropical cyclones over China. J Clim 33: 3731-3743. https://doi.org/10.1175/JCLI-D-19-0451.1

38. Mantua N, Hare S, Zhang Y, Wallace J, Francis R (1997) A Pacific Interdecadal Climate Oscillation with Impacts on Salmon Production. Bull Amer Meteor Soc 78: 1069-1080. https://doi.org/10.1175/1520-0477(1997)078<1069:APICOW>2.0.C0;2

39. Mei W, Xie SP, Zhao M, Wang Y (2015) Forced and Internal Variability of Tropical Cyclone Track Density in the Western North Pacific. J Clim 28: 143-167. https://doi.org/10.1175/JCLI-D-14-00164.1

40. Park D, Ho C, Kim J (2014) Growing threat of intense tropical cyclones to East Asia over the period 1977-2010. Environ Res Lett 9: 014008. https://doi.org/10.1088/1748-9326/9/1/014008

41. Patricola C, Camargo S, Klotzbach P, Saravanan R, Chang P (2018) The influence of ENSO flavors on western North Pacific tropical cyclone activity. J Clim 31: 5395-5416. https://doi.org/10.1175/JCLI-D17-0678.1

42. Ren H-L, Lu B, Wan J, Tian B, Zhang P (2018) Identification Standard for ENSO Events and Its Application to Climate Monitoring and Prediction in China. J Meteorol Res, 32: 923-936. https://doi.org/10.1007/s13351-018-8078-6

43. Sun Y, Zhong Z, Li T, Yi L, Shi J, Shen Y, Liu K, Hu Y, Xu Z (2020) Superiority of Mega-ENSO index in the seasonal prediction of tropical cyclone activity over the western North Pacific. Earth Space Sci 7: e2019EA001009. https://doi.org/10.1029/2019EA001009

44. Vitart F, Anderson J, Stern W (1997) Simulation of interannual variability of tropical storm frequency in an ensemble of GCM integrations. J Clim 10: 745-760. https://doi.org/10.1175/15200442(1997)010<0745:SOIVOT>2.0.C0;2

45. Wang B, Chan JCL (2002) How strong ENSO events affect tropical storm activity over the western North Pacific. J Clim 15: 1643-1658. https://doi.org/10.1175/15200442(2002)015<1643:HSEEAT>2.0.C0;2

46. Wang B, Liu J, Kim H-J, Webster P, Yim S-Y, Xiang B (2013c) Northern Hemisphere summer monsoon intensified by mega-El Niño/Southern Oscillation and Atlantic multidecadal oscillation. Proc Natl Acad Sci U S A 110: 5347-5352. https://doi.org/10.1073/pnas.1219405110

47. Wang B, Xiang B, Lee J-Y (2013b) Subtropical High predictability establishes a promising way for monsoon and tropical storm predictions. Proc Natl Acad Sci U S A, 110: 2718-2722. https://doi.org/10.1073/pnas.1214626110

48. Wang C, Li C, Mu M, Duan W (2013a) Seasonal modulations of different impacts of two types of ENSO events on tropical cyclone activity in the western North Pacific. Clim Dyn 40: 2887-2902. https://doi.org/10.1007/s00382-012-1434-9

49. Wang C, Wu L, Zhao H, Cao J, Tian W (2019) Is there a quiescent typhoon season over the western North Pacific following a strong El Niño event? Int J Climatol 39: 61-73. 
50. Wang S, Toumi R (2021) Recent migration of tropical cyclones towards coasts. Science, 371: 514517. https://doi.org/10.1126/science.abb9038

51. Winton M (2000) A reformulated three-layer sea ice models. J Atmos Ocean Tech 17: 525-531. https://doi.org/10.1175/1520-0426(2000)0172.0.C0;2

52. Wu J, Ren H, Zhang S, Liu Y, Liu X (2017) Evaluation and predictability analysis of seasonal prediction by BCC second-generation climate system model. Chin J Atmos Sci 41: 1300-1315. https://doi.org/10.3878/j.issn.1006-9895.1703.16256

53. Wu L, Wen Z, Huang R, Wu R (2012) Possible Linkage between the Monsoon Trough Variability and the Tropical Cyclone Activity over the Western North Pacific. Mon Wea Rev 140: 140-150. https://doi.org/10.1175/MWR-D-11-00078.1

54. Wu L, Zhang H, Chen J-M, Feng T (2018) Impact of two types of El Niño on tropical cyclones over the western North Pacific: Sensitivity to location and intensity of Pacific warming. J Clim 31: 1725-1742. https://doi.org/10.1175/JCLI-D-17-0298.1

55. Wu T, Li W, Ji J, Xin X, Li L, Wang Z, Zhang Y, Li J, Zhang F, Wei M, Shi X, Wu F, Zhang L, Chu M, Jie W, Liu Y, Wang F, Liu X, Li Q, Dong M, Liang X, Gao Y, Zhang J (2013) Global carbon budgets simulated by the Beijing Climate Center Climate System Model for the last century. J Geophys Res: Atmos 118: 4326-4347. https://doi.org/10.1002/jgrd.50320

56. Wu T, Song L, Li W, Wang Z, Zhang H, Xin X, Zhang Y, Zhang L, Li J, Wu F, Liu Y, Zhang F, Shi X, Chu M, Zhang J, Fang Y, Wang F, Lu Y, Liu X, Wei M, Liu Q, Zhou W, Dong M, Zhao Q, Ji J, Li L, Zhou M (2014) An Overview of BCC Climate System Model Development and Application for Climate Change Studies. J Meteor Res 28: 34-56. https://doi.org/10.1007/s13351-014-3041-7

57. Ye M, Wu J, Wang C, He X (2019) Historical and future changes in asset value and GDP in area exposed to tropical cyclones in China. Wea Clim Soc 11: 307-319. https://doi.org/10.1175/WCAS-D18-0053.1

58. Ying M, Zhang W, Yu H, Lu X, Feng J, Fan Y, Zhu Y, Chen D (2014) An overview of the China Meteorological Administration Tropical Cyclone Database. J Atmos Ocean Tech 31: 287-301. https://doi.org/10.1175/JTECH-D-12-00119.1

59. Yonekura E, Hall TM (2014) ENSO effect on East Asian tropical cyclone landfall via changes in tracks and genesis in a statistical model. J Appl Meteor Climatol 53: 406-420. https://doi.org/10.1175/JAMC-D-12-0240.1

60. Zhan R, Wang Y, Ying M (2012) Seasonal forecasts of tropical cyclone activity over the western North Pacific: A review. Trop Cyc Res Rev 1: 307-324. https://doi.org/10.6057/2012TCRR03.07

61. Zhan R, Wang Y, Zhao J (2017) Intensified Mega-ENSO Has Increased the Proportion of Intense Tropical Cyclones Over the Western Northwest Pacific Since the Late 1970s. Geophy Res Lett 44: 11959-11966. https://doi.org/10.1002/2017GL075916

62. Zhang D, Martin G, Rodríguez J, Ke Z, Chen L (2020) Predictability of Western Pacific Subtropical High Associated With Different ENSO Phases by GloSea5. J Meteor Res 34: 926-940. 55-1 
63. Zhang H, Wu L, Huang R, Chen J-M, Feng T (2020) Does the Pacific meridional mode dominantly affect tropical cyclogenesis in the western North Pacific? Clim Dyn 55: 3469-3483. https://doi.org/10.1007/s00382-020-05457-2

64. Zhang Q, Wu L, Liu Q (2009) Tropical cyclone damage in China 1983-2006. Bull Amer Meteor Soc 90: 489-496. https://doi.org/10.1175/2008BAMS2631.1

65. Zhao H, Klotzbach P, Chen S (2020) Dominant influence of ENSO-like and global sea surface temperature patterns on changes in prevailing boreal summer tropical cyclone tracks over the western North Pacific. J Clim 33:9551-9565. https://doi.org/10.1175/JCLI-D-19-0774.1

66. Zhao H, Wu L (2014) Inter-decadal shift of the prevailing tropical cyclone tracks over the western North Pacific and its mechanism study. Meteor Atmos Phys 125: 89-101. https://doi.org/10.1007/s00703-014-0322-8

67. Zhao H, Wu L, Zhou W (2010) Assessing the influence of the ENSO on tropical cyclone prevailing tracks in the western North Pacific. Adv Atmos Sci 27: 1361-1371. https://doi.org/10.1007/s00376010-9161-9

68. Zhao J, Zhan R, Wang Y, Xu H (2018) Contribution of the Interdecadal Pacific Oscillation to the recent abrupt decrease in tropical cyclone genesis frequency over the western North Pacific since 1998. J Clim 31: 8211-8224. https://doi.org/10.1175/JCLI-D-18-0202.1

69. Zhao K, Zhao H, Raga G, Yoshida R, Wang W, Klotzbach P (2021) Changes in extended boreal summer tropical cyclogenesis associated with large-scale flow patterns over the western North Pacific in response to the global warming hiatus. Clim Dyn 56: 515-535. https://doi.org/10.1007/s00382-020-05486-x

\section{Figures}


(a) EOF1

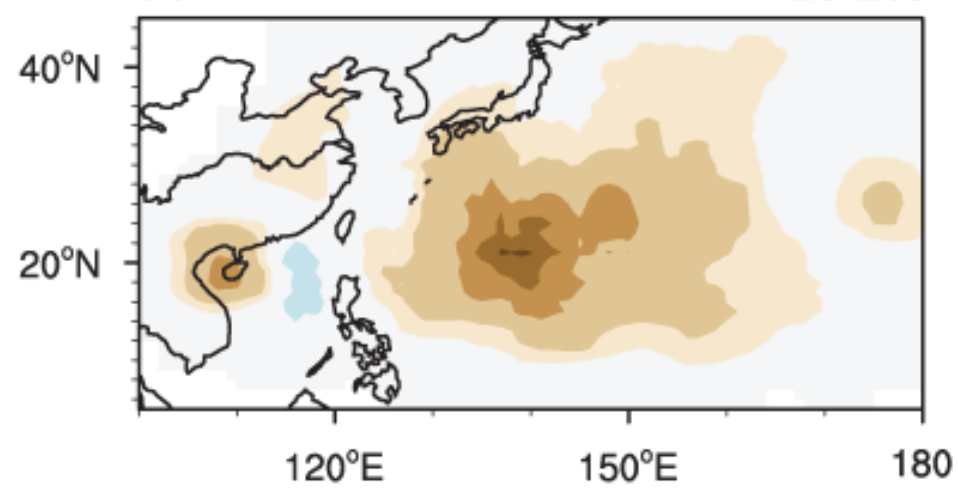

(c) EOF2
$20.2 \%$

$14.3 \%$

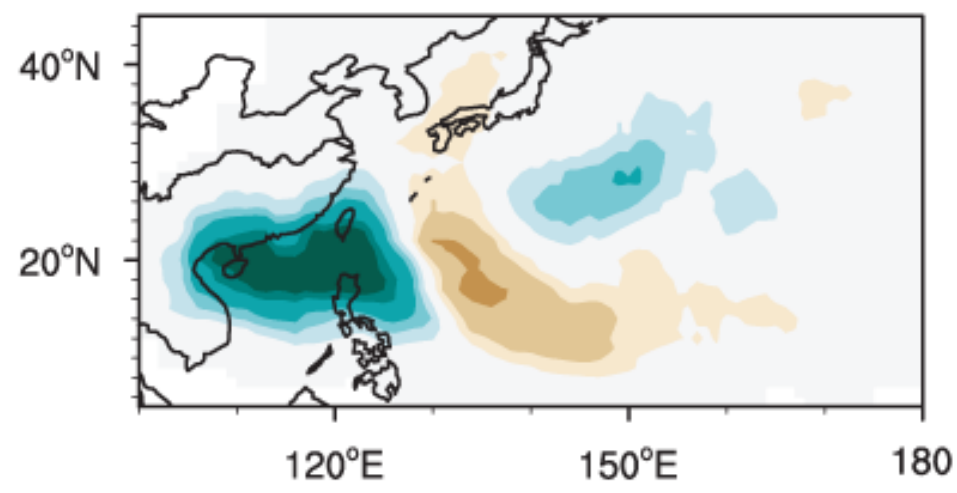

(e) EOF3

$8.7 \%$

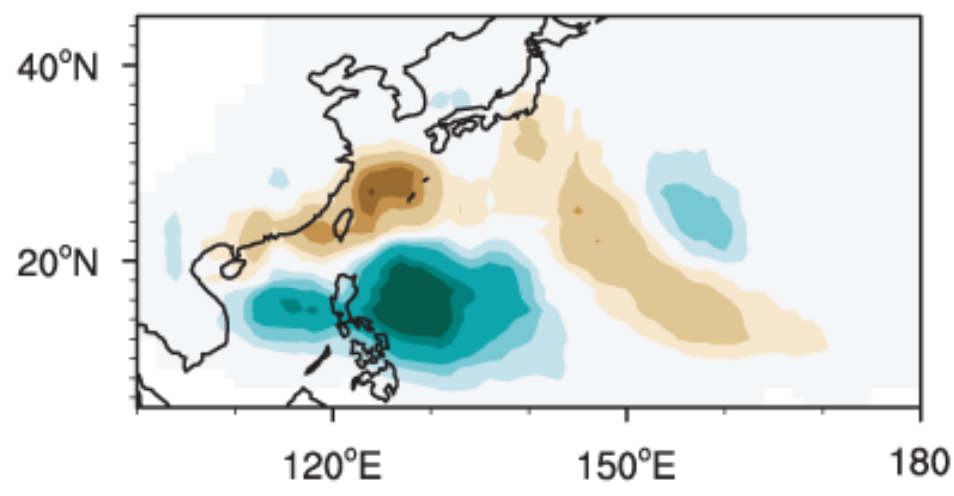

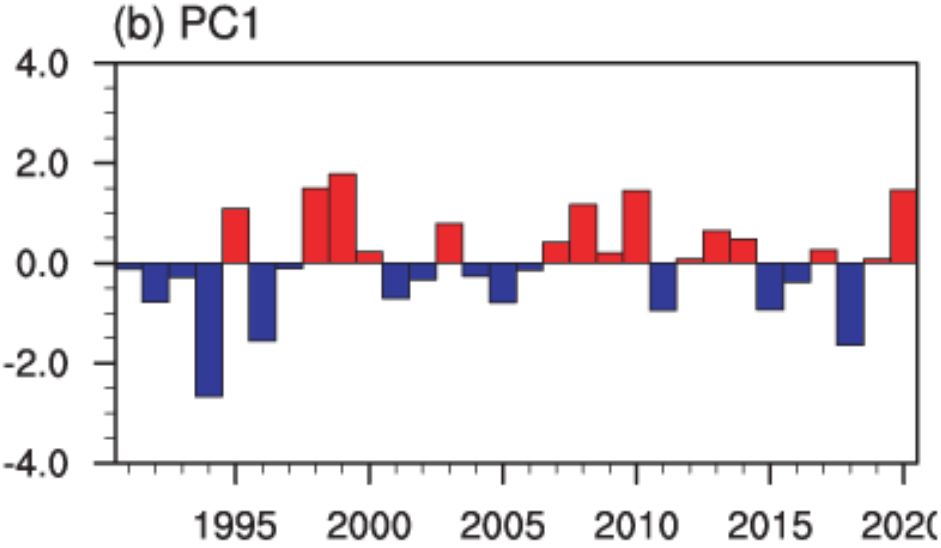

(d) PC2

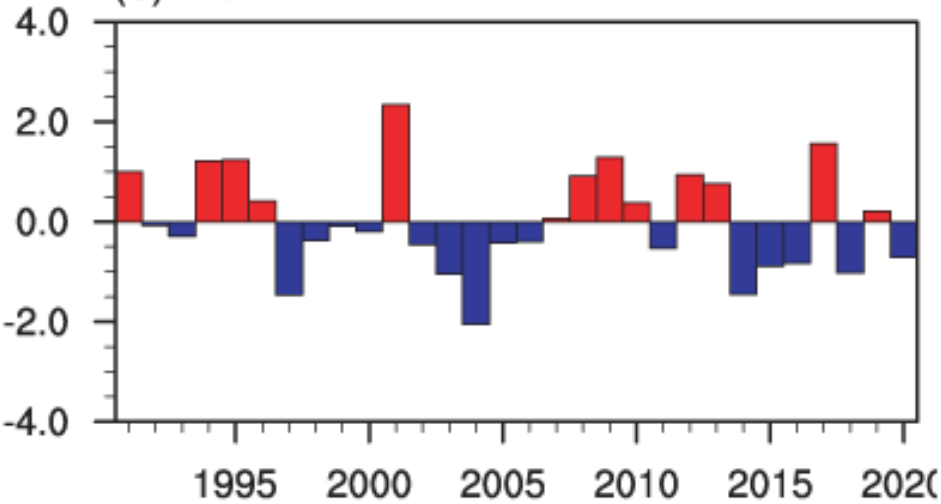

(f) PC3

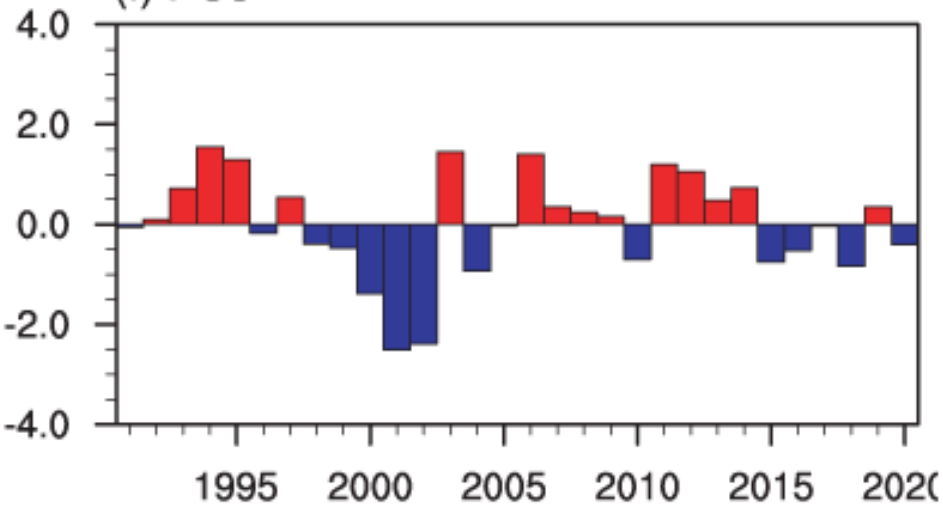

\begin{tabular}{c|c|c|c|c|c|c|}
\hline & $\mid$ & $\mid$ & $\mid$ & $\mid$ & $\mid$ \\
-0.06 & -0.04 & -0.02 & 0.01 & 0.03 & 0.05
\end{tabular}

Figure 1

EOF analysis of inter-annual variations of TC tracks density spatial distribution over WNP of July, August and September (JAS) from 1991 to 2020. a, c and e denotes the spatial patterns and the percentage (normalized) variance of the first and second EOF mode. $b, d$ and $f$ are the associated time series. 
(a) Corr.(PC1 \& SST.Obs)

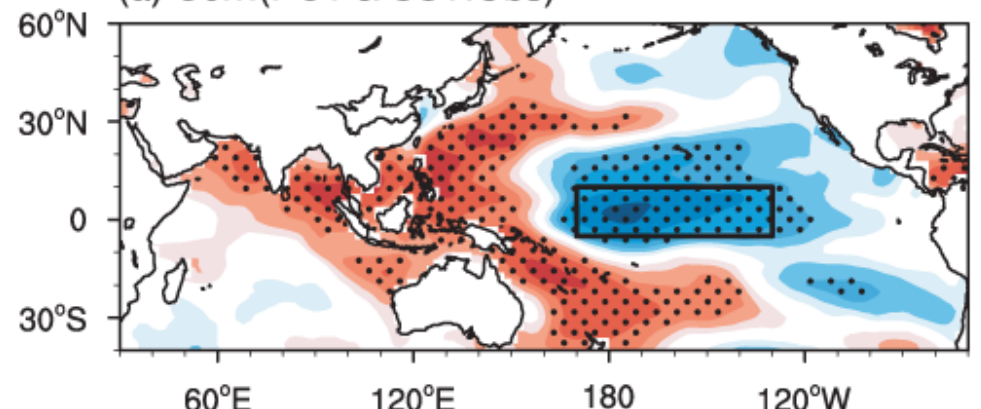

(c) Corr.(PC1 \& H850.Obs)

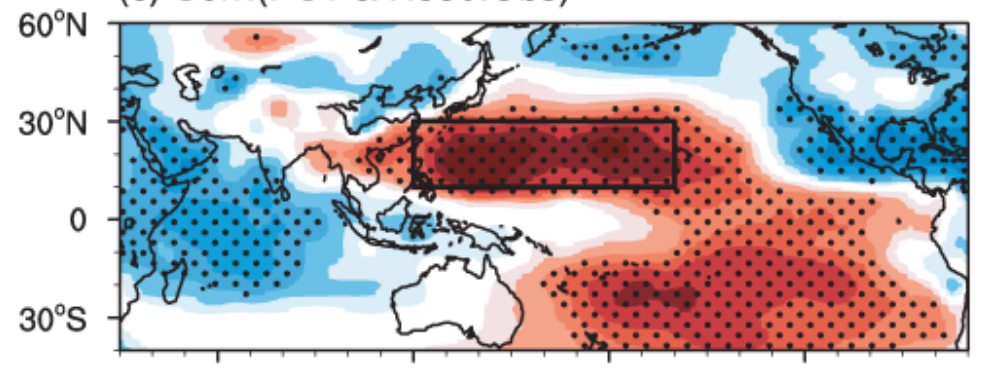

$60^{\circ} \mathrm{E} \quad 120^{\circ} \mathrm{E}$

(e) Corr.(PC1 \& VWS.Obs)

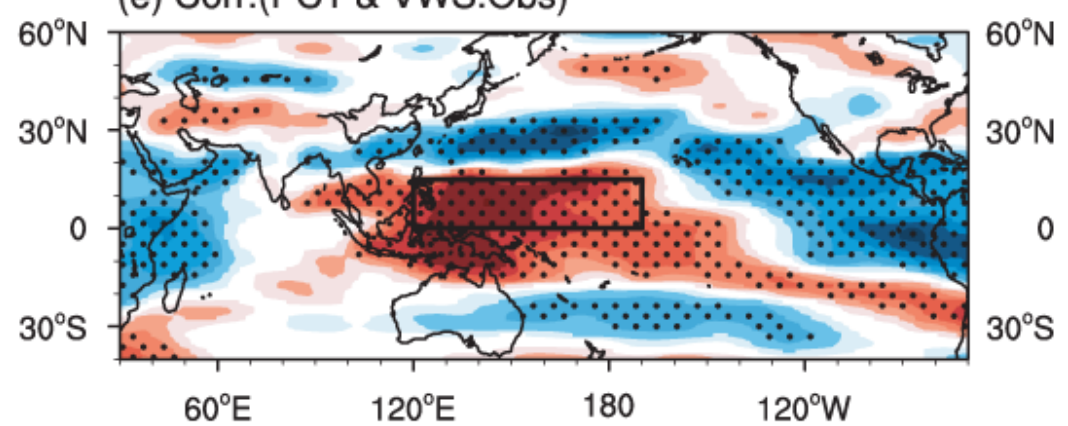

(b) Corr.(PC1 \& SST.CSM)

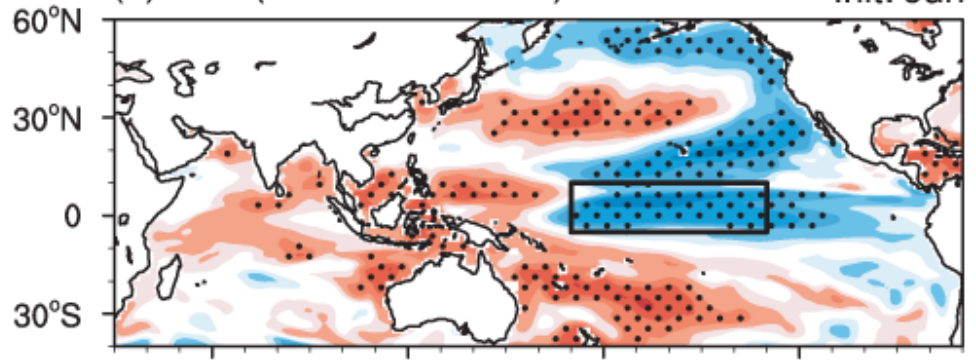

$60^{\circ} \mathrm{E}$

$120^{\circ} \mathrm{E}$

180

$120^{\circ} \mathrm{W}$

(d) Corr.(PC1 \& H850.CSM) Init: Jun

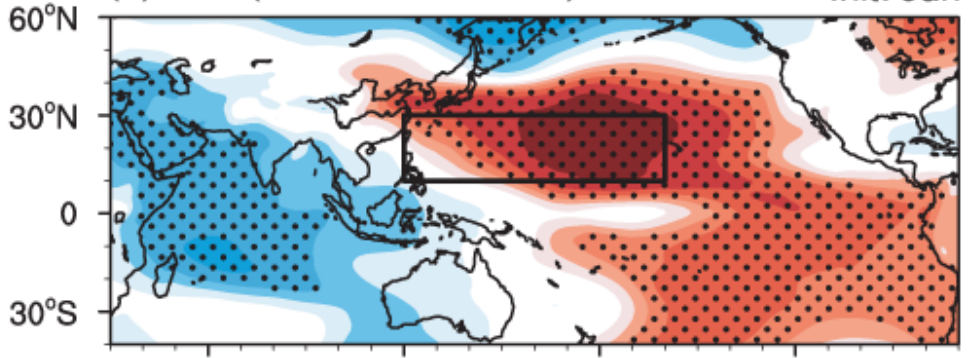

$60^{\circ} \mathrm{E}$

$120^{\circ} \mathrm{E}$

180

$120^{\circ} \mathrm{W}$

(f) Corr.(PC1 \& VWS.CSM) Init: Jun

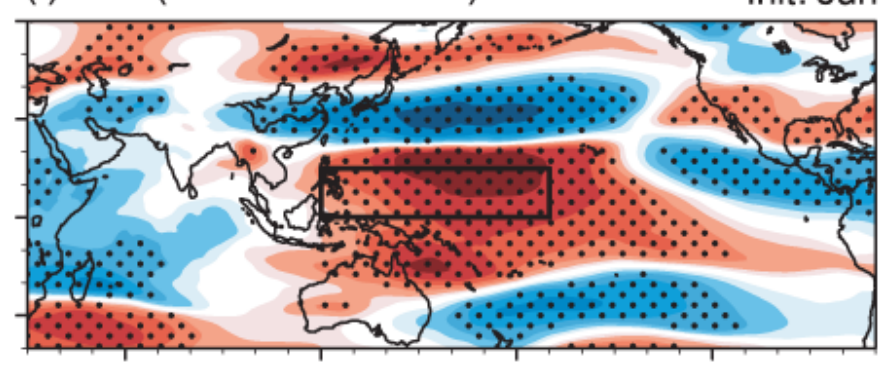

$60^{\circ} \mathrm{E}$

180

$120^{\circ} \mathrm{W}$

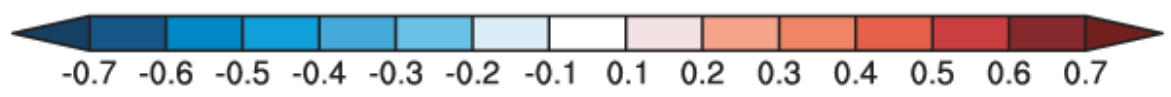

Figure 2

ACC between PC1 and observational a SST anomalies, c H850 and e VWS and b, d, f BCC-CSM1.1 hindcast initiated in June. Dotted area indicates correlation coefficients passing significant test at $90 \%$ confidence level. 
(a) Corr.(PC2 \& SST.Obs)

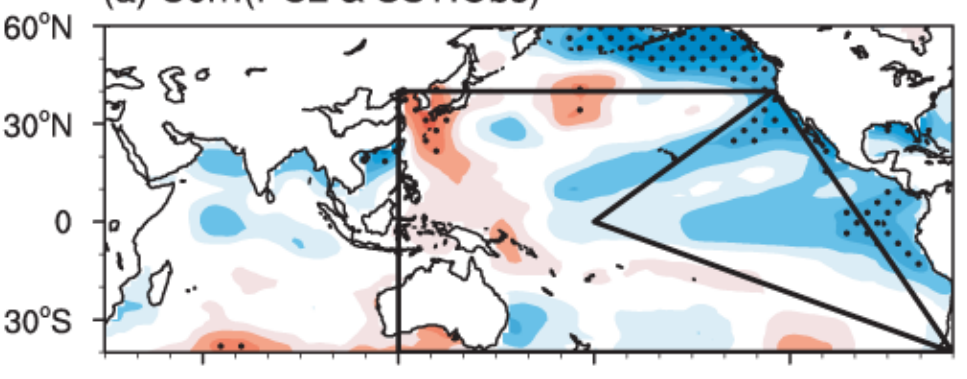

$60^{\circ} \mathrm{E} \quad 120^{\circ} \mathrm{E}$

(c) Corr.(PC2 \& OLR.Obs)

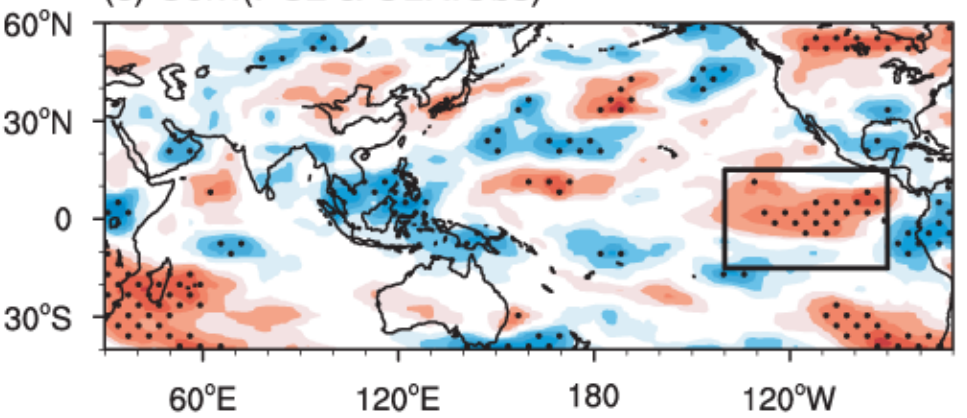

(b) Corr.(PC2 \& SST.CSM)

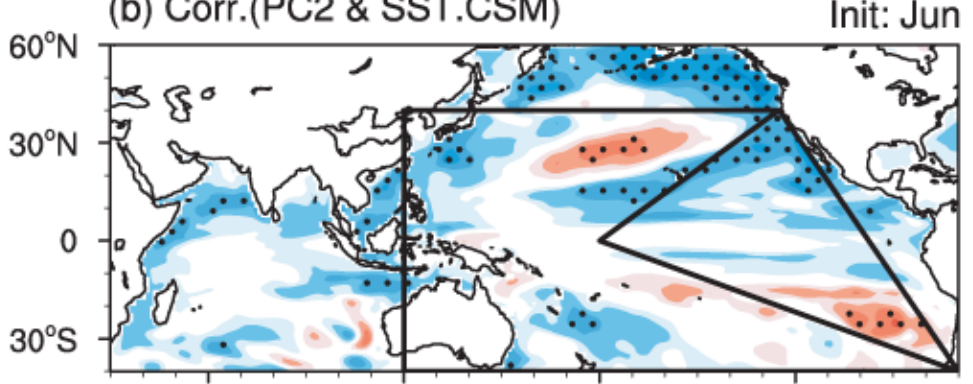

$60^{\circ} \mathrm{E}$

$120^{\circ} \mathrm{W}$

(d) Corr.(PC2 \& OLR.CSM)

Init: Jun

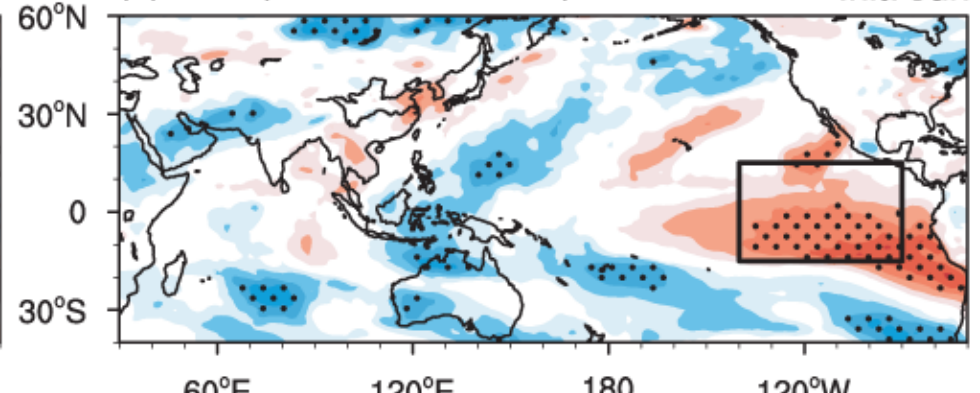

$60^{\circ} \mathrm{E}$

$120^{\circ} \mathrm{E}$

$120^{\circ} \mathrm{W}$

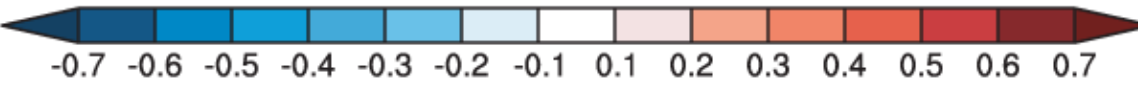

\section{Figure 3}

ACC between PC2 and observational a SST anomalies, c OLR and c, d BCC-CSM1.1 hindcast initiated in June. Dotted area indicates correlation coefficients passing significant test at $90 \%$ confidence level.

(a) Corr.(PC3 \& SST.Obs)

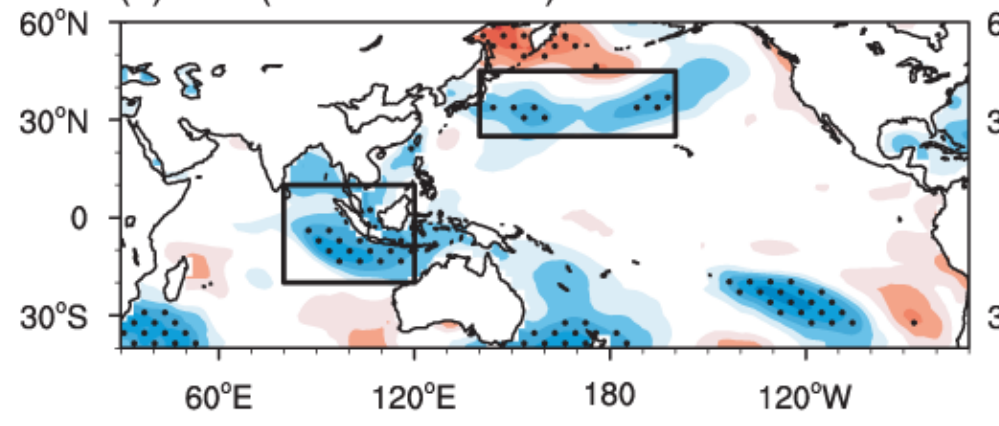

(b) Corr.(PC3 \& SST.CSM)

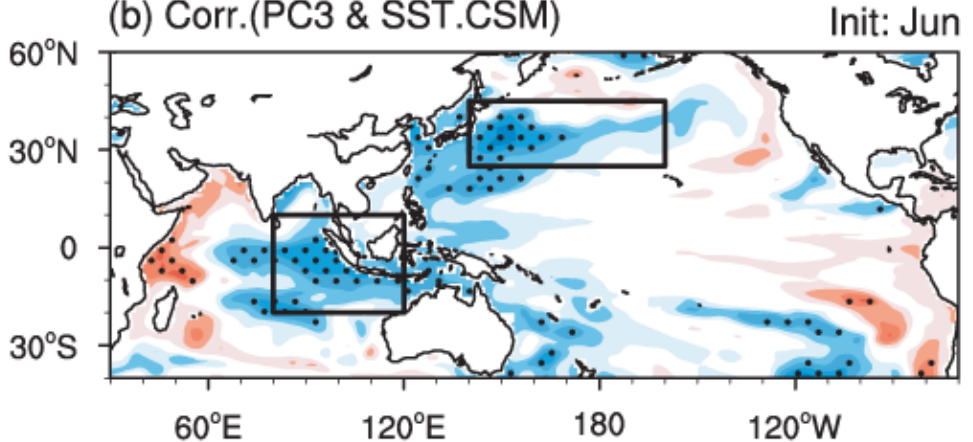

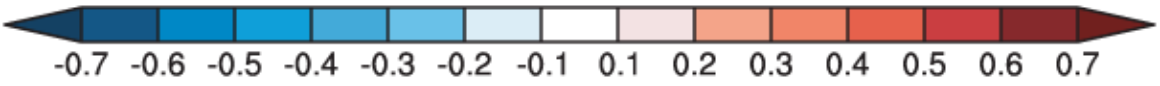

\section{Figure 4}

ACC between PC3 and a observational SST anomalies and b BCC-CSM1.1 hindcast initiated in June. Loading [MathJax]/jax/output/CommonHTML/jax.js 3 passing significant test at $90 \%$ confidence level. 
(a) SST

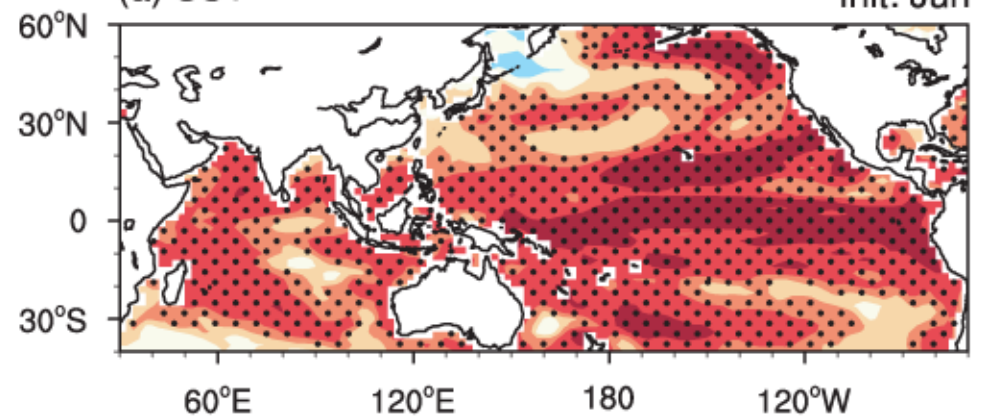

(c) VWS

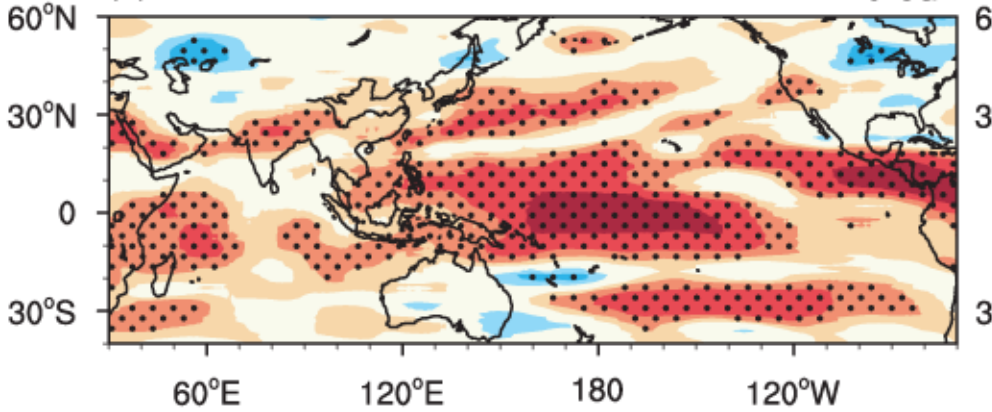

$60^{\circ} \mathrm{E}$ (b) $\mathrm{H} 850$

Init: Jun

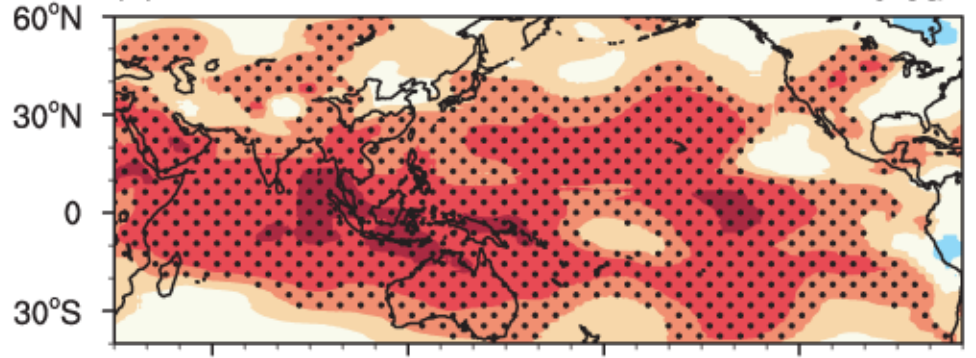

$60^{\circ} \mathrm{E}$

$120^{\circ} \mathrm{E}$

$180 \quad 120^{\circ} \mathrm{W}$

(d) OLR

Init: Jun
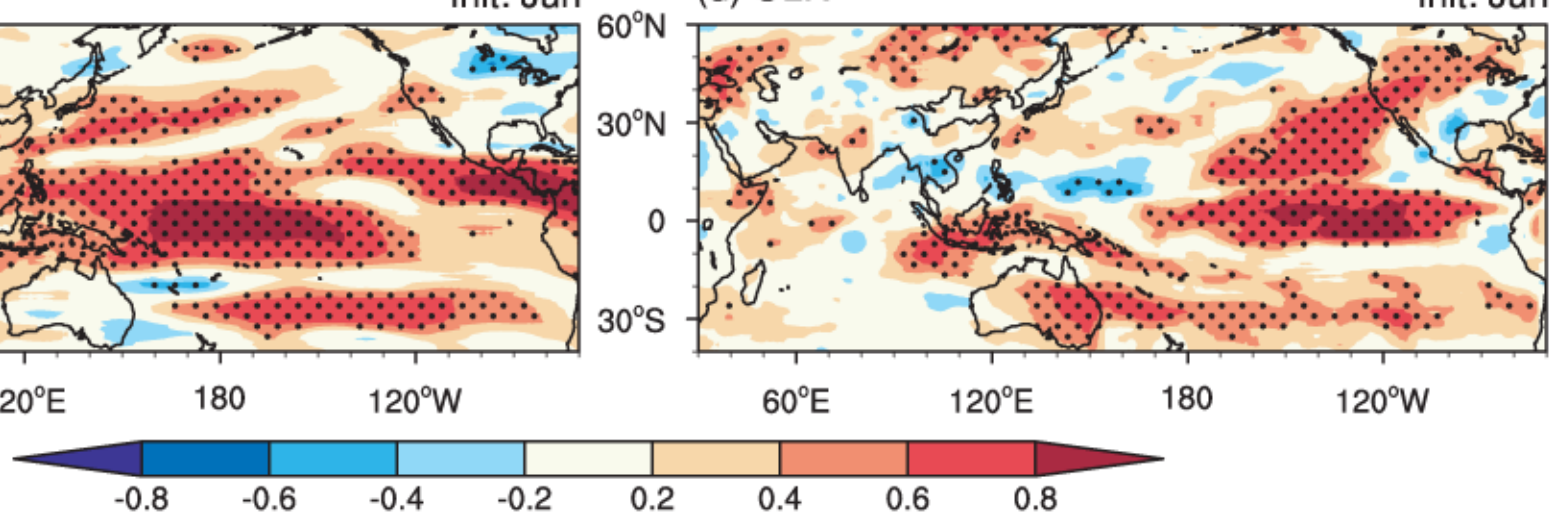

\section{Figure 5}

ACC between BCC-CSM1.1 hindcast initiated in June and observational SST anomaly (a), H850 (b), VWS (c) and OLR (d). Dotted area indicates correlation coefficients passing significant test at $95 \%$ confidence level. 
(a) PC1

Init: Jun
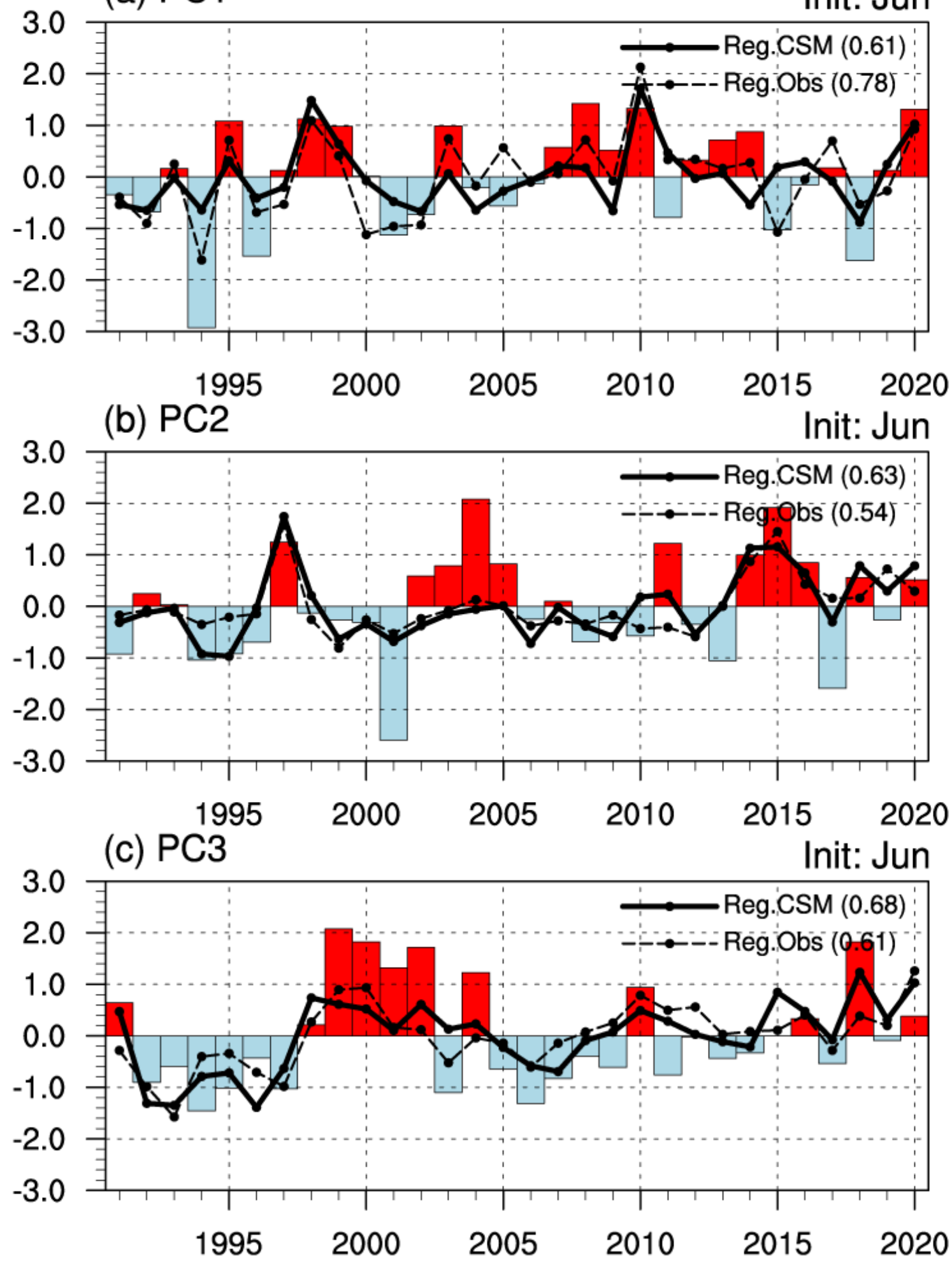

Figure 6

Regressed inter-annual variation of time series associated with a PC1, b PC2 and c PC3 based on selected predictors of observational and BCC-CSM1.1 hindcast initiated in June. The figures in brackets in legend denote ACC between PCs and regressed results based on observational and BCC-CSM1.1 hindcast data respectively. 
(a) PC1

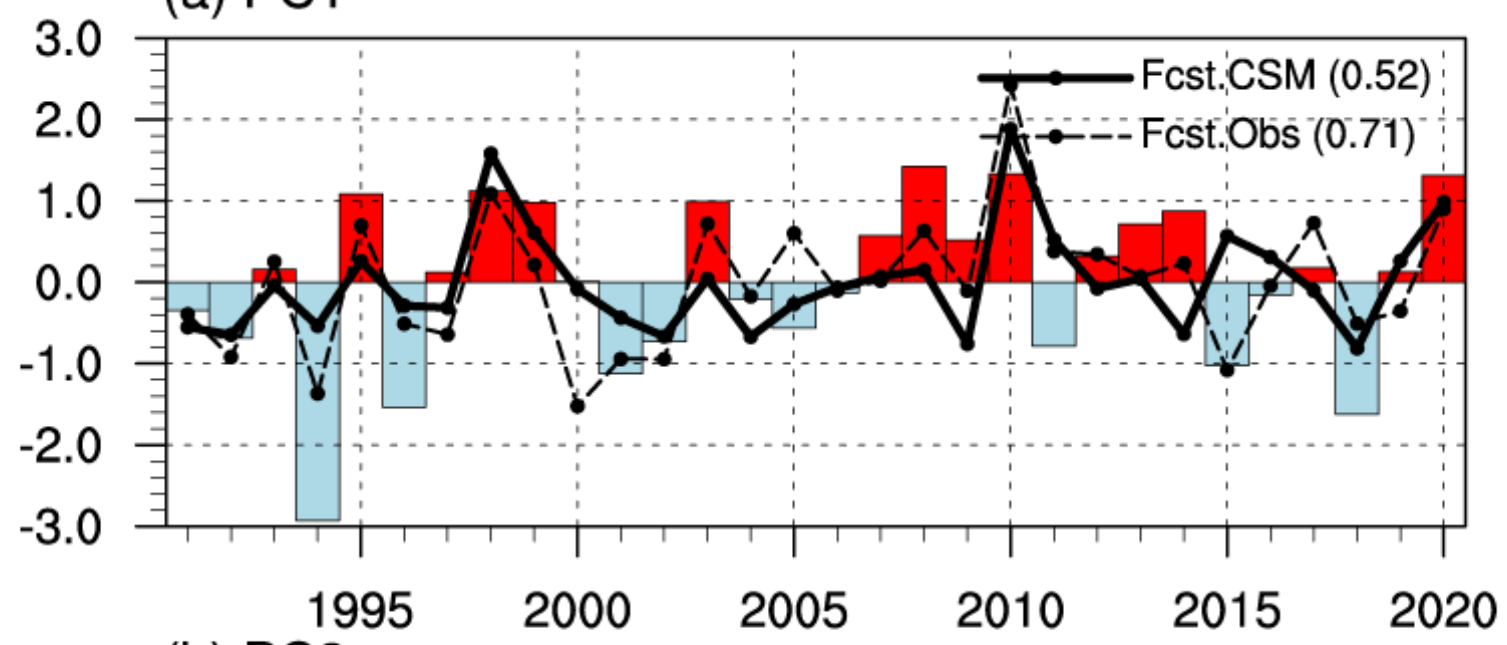

(b) PC2

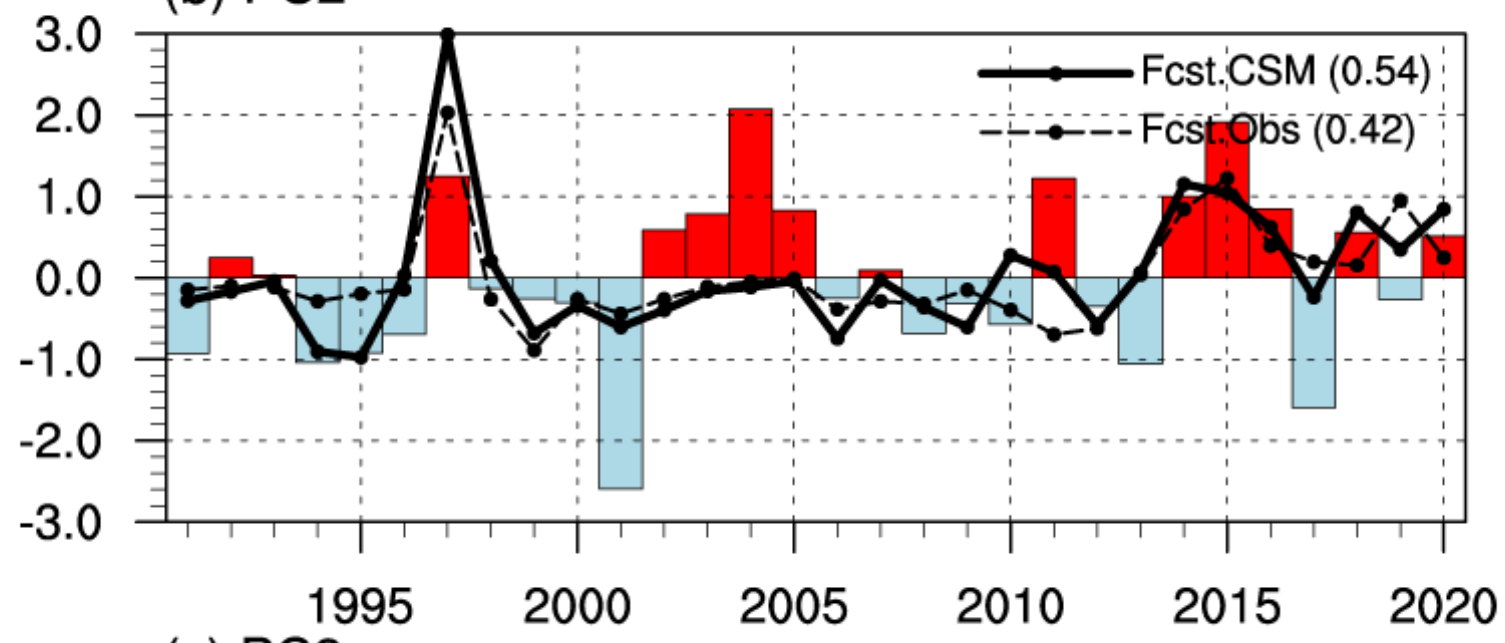

(c) $\mathrm{PC} 3$

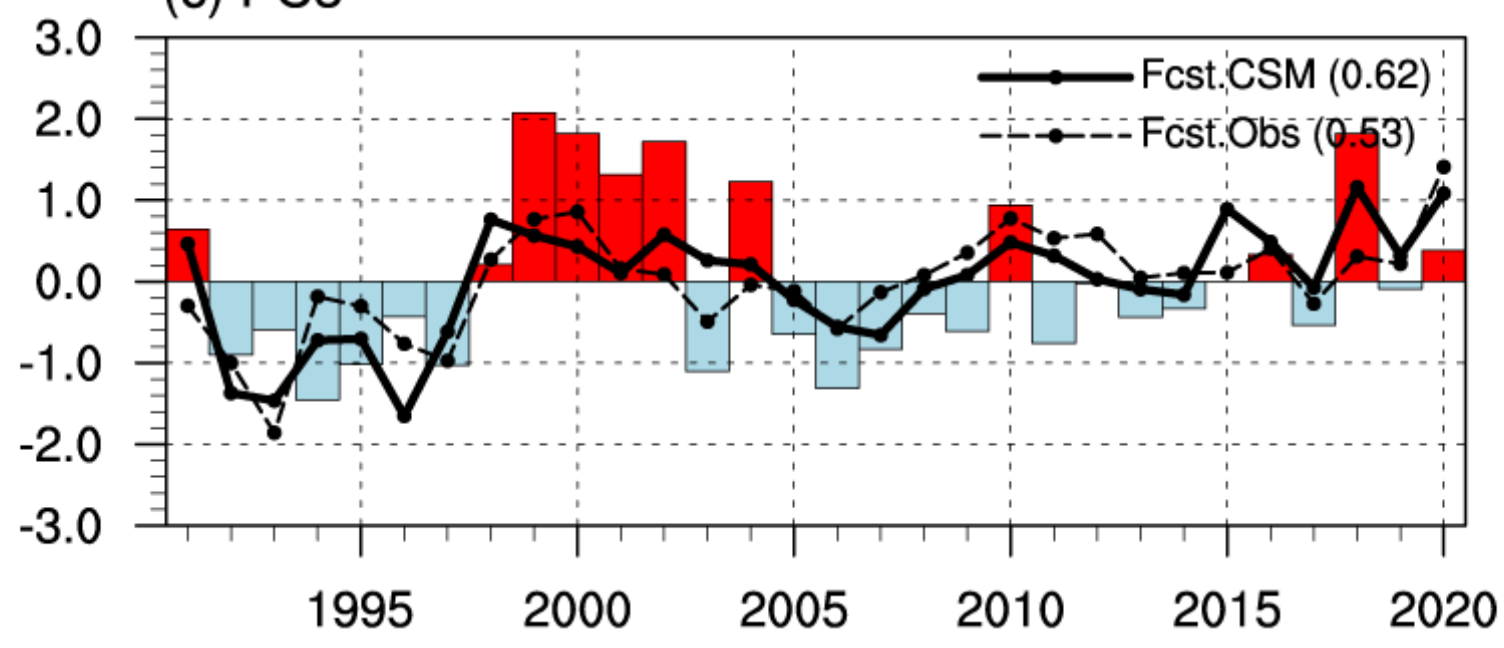

Figure 7

Independent sample test (one-year-out) of predicted inter-annual variation of time series associated with a PC1, b PC2 and c PC3 based on selected predictors of observational and BCC-CSM1.1 hindcast initiated in June. The figures in brackets in legend denote ACC between PCs and regressed results based on observational and BCC-CSM1.1 hindcast respectively. 


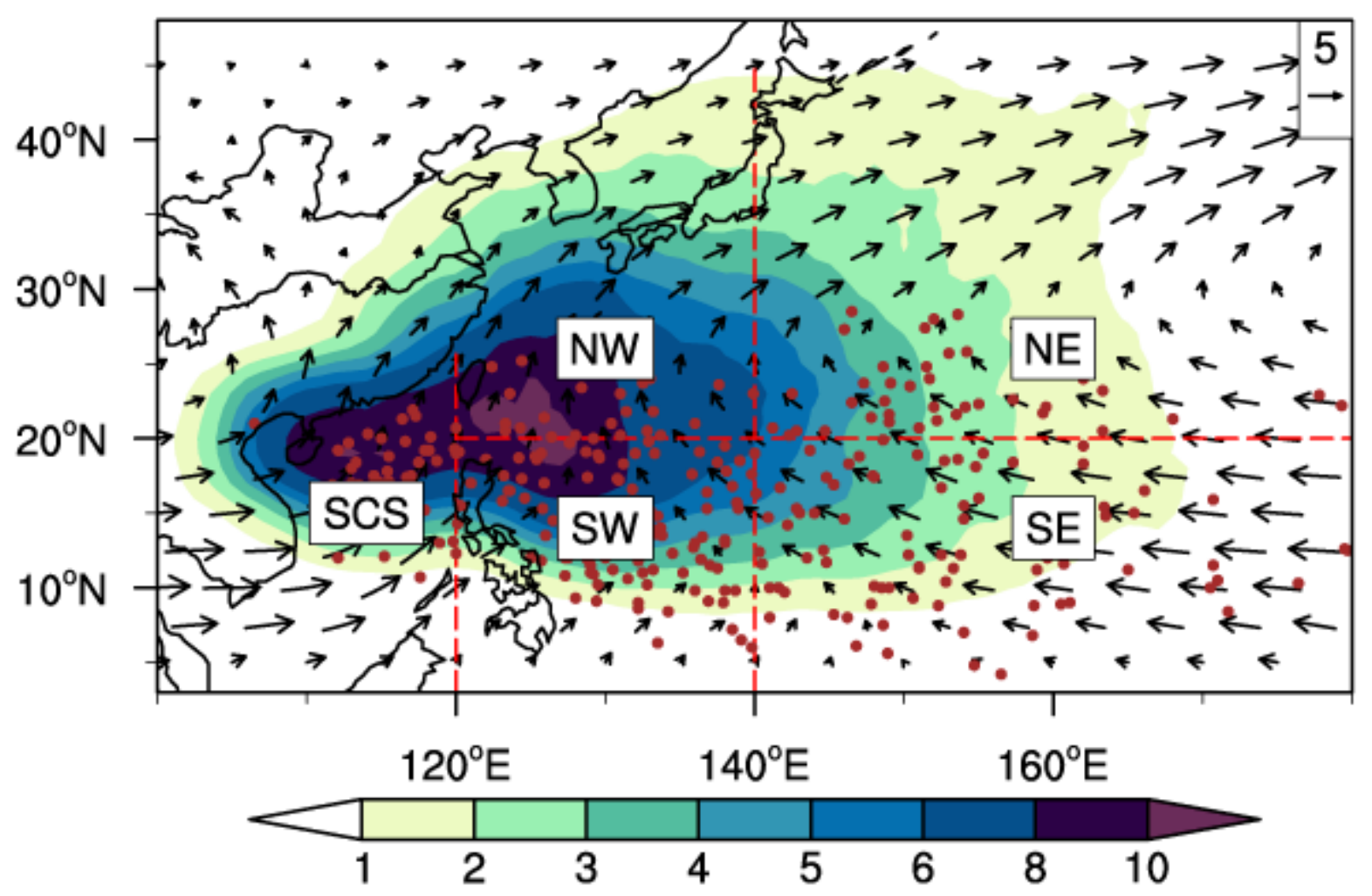

Figure 8

Spatial distribution of the Climatology of TC track density (Shading) and 850hPa wind field (Vector, $\mathrm{m} / \mathrm{s}$ ) over WNP from July to September. The WNP is divided into 4 sub-regions: NW, NE, SW and SE. Brown dots represent locations of all TC genesis from 1991 to 2020. 


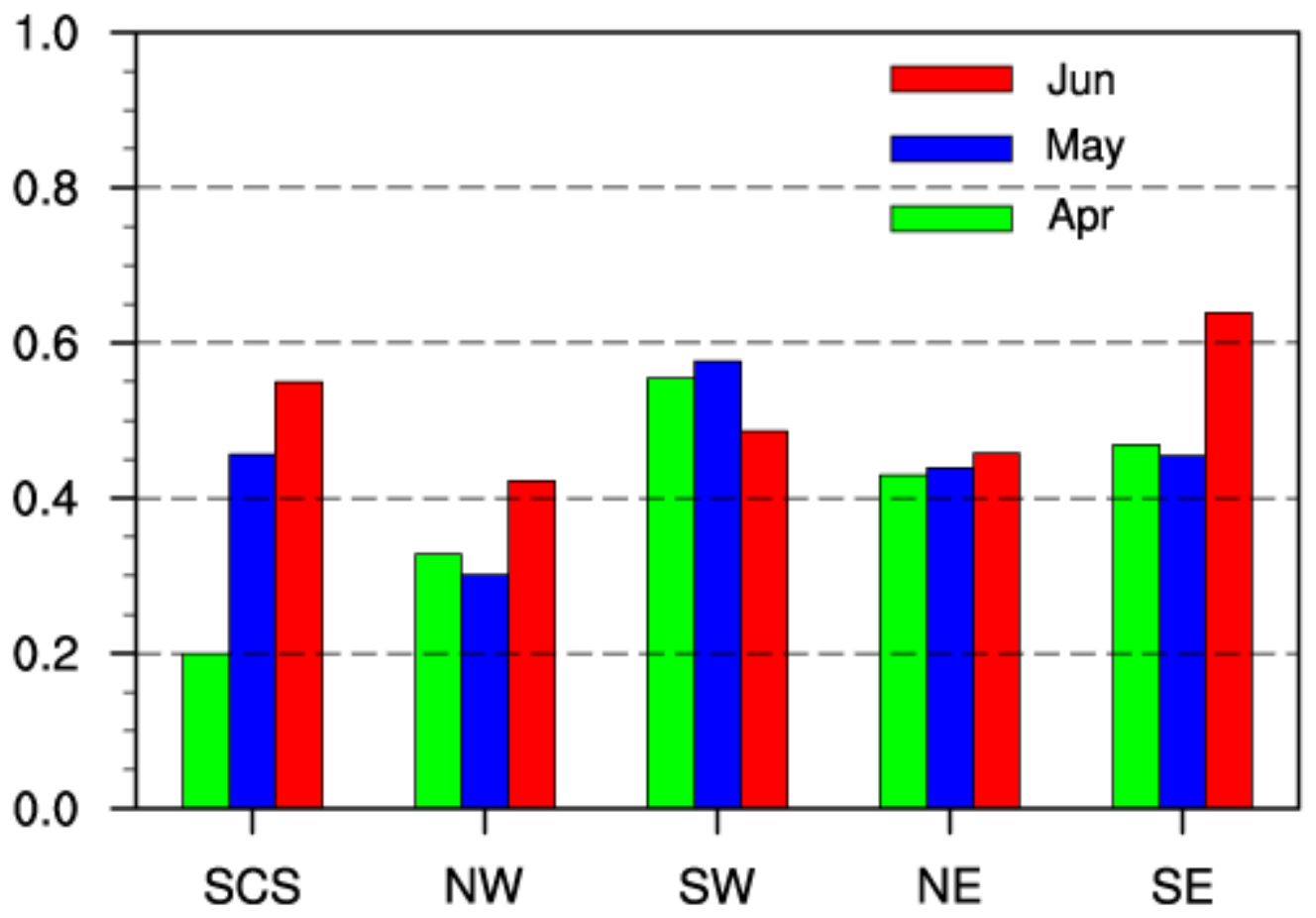

Figure 9

ACC between forecast and observations of mean TC track density within each sub regions initiated from April (green), May (blue) and June (red)

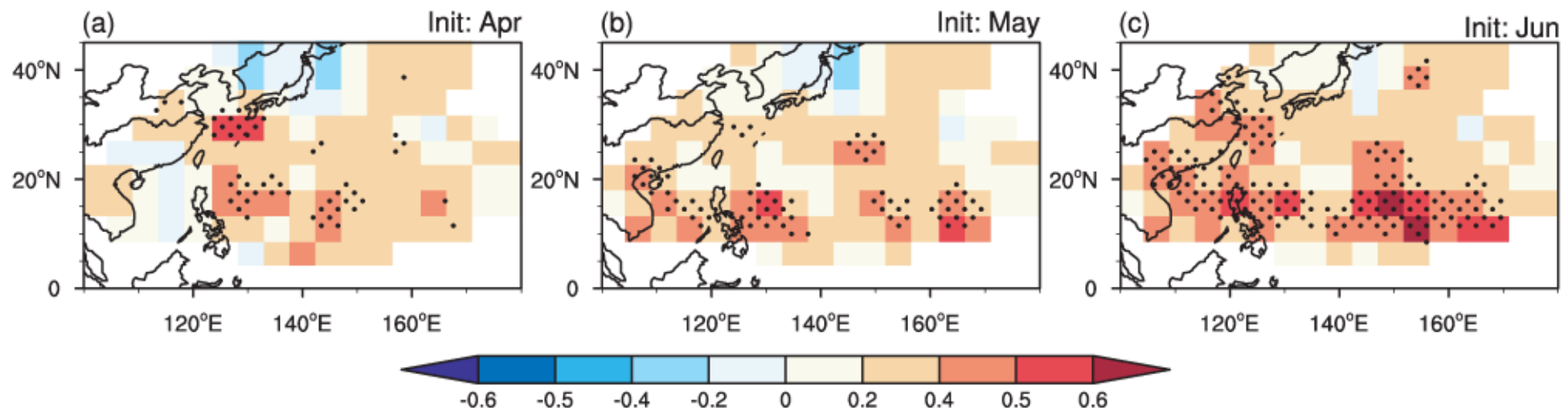

Figure 10

Spatial distribution of ACC between forecast and observations of TC track density in JAS initiated from April (a), May (b) and June (c). Dotted area indicates correlation coefficients passing significant test at Loading [MathJax]/jax/output/CommonHTML/jax.js 
(a) El Nino

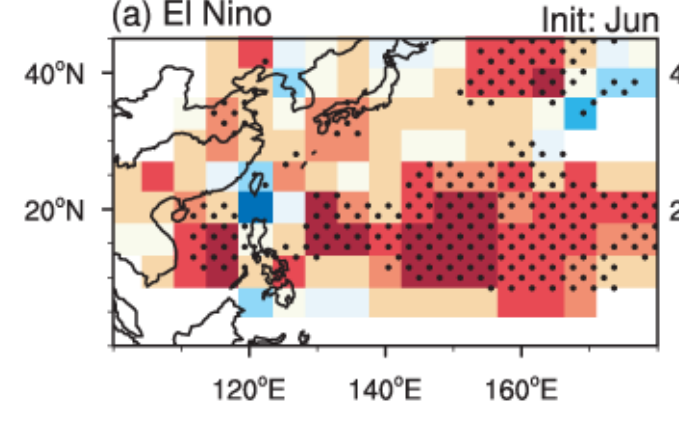

$120^{\circ} \mathrm{E} \quad 140^{\circ} \mathrm{E} \quad 160^{\circ} \mathrm{E}$ (b) Neutral

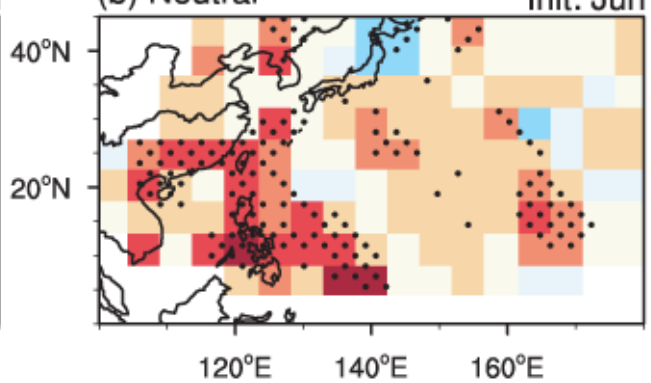

(c) La Nina $40^{\circ} \mathrm{N}$ $40 \mathrm{~N}$ $20^{\circ} \mathrm{N}$

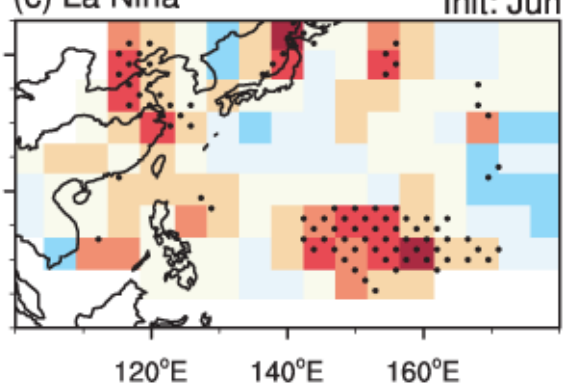

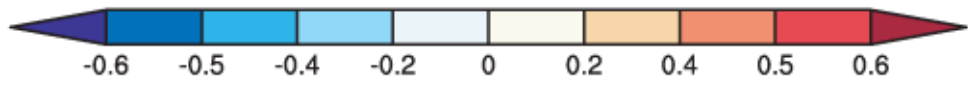

\section{Figure 11}

Spatial distribution of ACC between forecast and observations of TC track density in JAS of a El Niño decaying, b Neutral and c La Niña decaying years initiated from June. Dotted area indicates correlation coefficients passing significant test at 95\% confidence level.

(a) El Nino

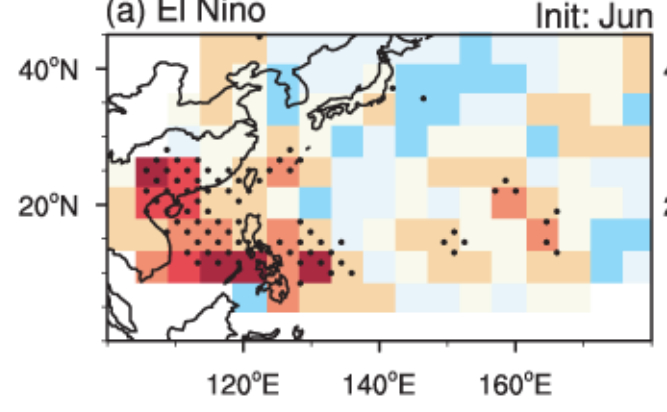

$120^{\circ} \mathrm{E} \quad 140^{\circ} \mathrm{E} \quad 160^{\circ} \mathrm{E}$ (b) Neutral

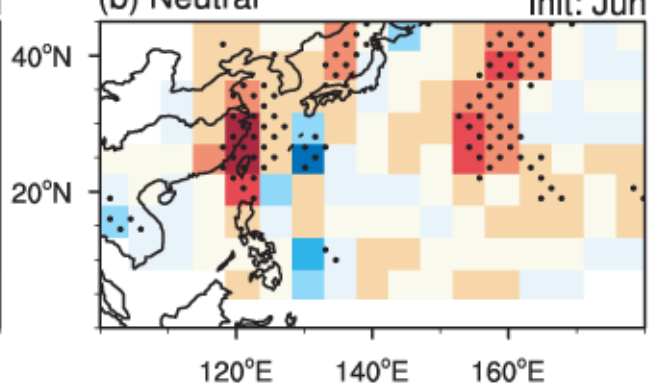

(c) La Nina

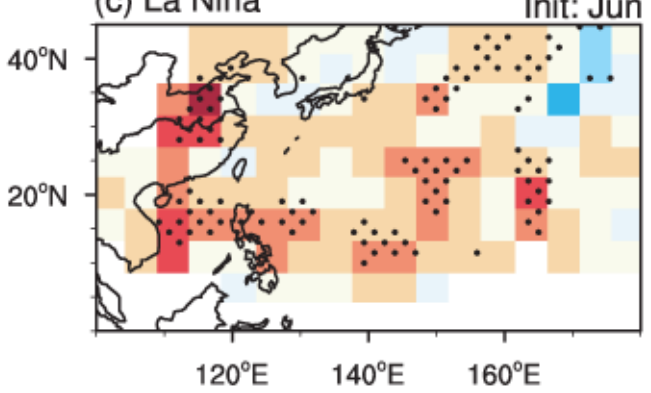

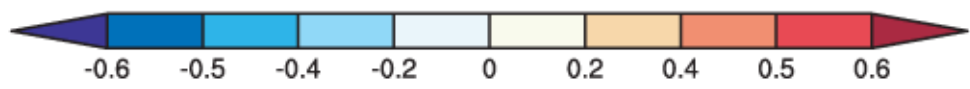

Figure 12

Same with Fig. 11 but for a El Niño developing, b Neutral and c La Niña developing years 